Public-data Flle 91-25

\title{
INDEX OF SURFICIAL GEOLOGIC MAPS IN ALASKA
}

\author{
by \\ D.S. Pinney \\ Alaska Division of \\ Geological and Geophysical Surveys
}

June 1991

THIS REPORT HAS NOT BEEN REVIEWED FOR TECHNICAL CONTENT (EXCEPT AS NOTED IN TEXT) OR FOR CONFORMITY TO THE EDITORIAL STANDARDS OF DGGS.

794 University Avenue, Suite 200

Fairbanks, Alaska 99709-3645 


\title{
INDEX OF SURFICIAL GEOLOGIC MAPS IN ALASKA
}

By

\author{
DeAnne S. Pinney
}

\section{CONTENTS}

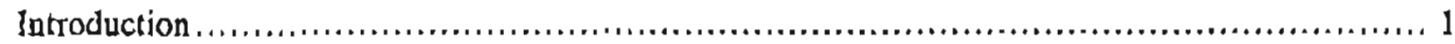

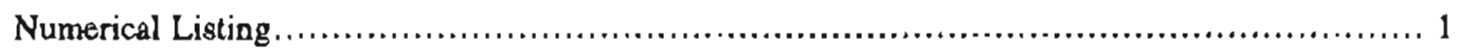

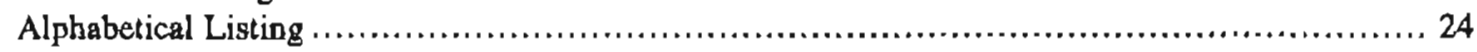

\section{INTRODUCTION}

This index was compiled to identify areas of surficial geologic mapping in Alaska and to provide a bibliography of publications that address surficial deposits in at least moderate detail. Source material is confined to publications of the AJaska Division of Geological and Geophysical Surveys and the U.S. Geological Survey. Publications listings were consulted to identify likely titles and the corresponding publications were examined and assessed for degree of detail in the mapping of surficial deposits. This index should not be regarded as comprehensive, for there may be publications containing surficial geologic maps with titles that give no such indication.

Mapped areas from selected publications are shown on Plate 1 and keyed by number to the following numerical and alphabetical listings.

\section{NUMERICAL LISTING}

1. Wahrhaftig, Clyde, 1958, Quaternary geology of the Nenana River valley and adjacent parts of the Alaska Range: U.S. Geological Survey Professional Paper 293 A, p. 1-78, scale 1:63,360, 8 sheets.

2. Buffler, R.T., 1976, Geologic map of south Augustine Island, lower Cook Inlet: Alaska Division of Geological and Geophysical Surveys Open-file Report 96, 3 p., scale 1:24,000, 1 sheet.

3. Gilbert, W.G., 1977, General geology and geochemistry of the Healy D-1 and southern Fairbanks A-1 quadrangles: Alaska Division of Geological and Geophysical Surveys Open-file Report 105, 10 p., scale 1:63,360, 2 sheets.

4. Reger, R.D., 1978, Reconnaissance geology of the Talkeetna-Kashwitna area, Susitna River basin: Alaska Division of Geological and Geophysical Surveys Open-file Report 107A, scale $1: 63,360,1$ sheet.

5. Reger, R.D., and Carver, C.L., 1978a, Reconnaissance map of geologic materials, TalkeetnaKashwitna area, Susitna River basin: Alaska Division of Geological and Geophysical Surveys Open-file Report 1078, scale 1:63,360, 1 sheet.

6. Kline, J.T., 1978, Stope map of the Talkeetna-Kashwitna area, Susitna River basin: Alaska Division of Geological and Geophysical Surveys Open-file Report 107C, scale 1:63,360, 1 sheet. 
7. Reger, R.D., 1977, Photointerpretive map of the surficial geology of the southera Kenai Lowlands: Alaska Division of Geological and Geophysical Surveys Open-file Report 111A, scale $1: 63,360,1$ sheet.

8. Reger, R.D., and Carver, C.L., 1977, Photointerpretive map of the geologic materials of the southern Kenai Lowlands: Alaska Division of Geological and Geophysical Surveys Open-file Report 111B, scale 1:63,360, 1 sheet.

9. Kline, J.T., 1977, Slope map of the southern Kenai Lowlends: Alaska Division of Geological and Geopbysical Surveys Open-file Report 111C, scale 1:63,360, 1 sheot.

10. Reger, R.D., and Carver, C.L., 1978b, Reconnaiscance geology of the new capital site and vicinity, Anchorage Quadrangle: Alaska Division of Geological and Geophysical Surveys Openfile Report 113A, scale 1:63,360, i sheet.

11. 1978c, Reconnaissance geologic materials map of the new capital site and vicinity, Anchorage Quadrangle: Alaska Division of Geological and Geophysical Surveys Open-file Report 1138, scale 1:63,360, 1 sheet.

12. Dillon, J.T., Hanilton, W.B., and Lueck, L.L., 1981, Geologic map of the Wiseman A-3 Quadrangle: Alaska Division of Geological and Geophysical Surveys Open-file Report 119, scale 1:63,360, 1 sheet.

13. Bundtzen, T.K., and Laird, G.M., 1980, Preliminary geology of the McGrath-Upper Innoko River area, western interior Alaska: Alaska Division of Geological and Geophysical Surveys Open-file Report 134, 36 p., scale 1:63,360, 2 sheets.

14. Kline, J.T., 1982, Surficial geology of the lower Pilgrim valley and vicinity, western Seward Peninsula: Alaska Division of Geological and Geophysical Surveys Open-file Report 140, scale $1: 63,360,2$ sheets.

15. Rawlinson, S.E.. Huck, R.W., and Hardy, S.B., 1982a, Peat-resource map, south-central Talkeetna B-1 Quadrangle: Alaska Division of Geological and Geophysical Surveys Open-file Report 150A, scale 1:15,840, 1 sheet.

16. 1982b, Peat-resource map, southwestern Talkeetna B-1 Quadrangle: Alaska Division of Geological and Geophysical Surveys Open-file Report 150B, scale 1:15,840, 1 sheet.

17. 1982c, Peat-resource map, north-central Talkeetna A-1 Quadrangle: Alaska Division of Geological and Geophysical Surveys Open-file Report 150C, scale 1:15,840, 1 sheet.

18. 1982d, Peat-resource map, northwestem Talkeetna A-1 Quadrangle: Alaska Division of Geological and Geophysical Surveys Open-file Report 150D, scale 1:15,840, 1 sheet.

19. 1982e, Peat-resource map, southeastern Talkeetna A-1 and southwestern Talkeetna Mountains A-6 quadrangles: Alaska Division of Geological and Geophysical Surveys Open-file Report 150E, scale 1:15,840, I sheet.

20. 1982f, Peat-resource map, south-central Talkeetna A-1 Quadrangle: Alaska Division of Geological and Geophysical Surveys Open-file Report 150R, scale 1:15,840, 1 sheet.

21. 1982g, Peat-resource map, southwestern Talkeetna A-1 Quadrangle: Alaska Division of Geological and Geophysical Surveys Open-file Report 150G, scale 1:31,680, 1 sheet. 
1982h, Peat-resource map, western Anchorage D-8 Quadrangle: Alaska Division of Geological and Geophysical Surveys Open-file Report 150H, scale 1:31,680, 1 sheet.

23. 1982i, Peat-resource map, Tyonek D-1 Quadrangle: Alaska Division of Geological and Geophysical Surveys Open-file Report 1501, scale 1:31,680, I sheet.

24. 1982j, Peat-resource map, Anchorage C-8 Quadrangle: Alaska Division of Geological and Geophysical Surveys Open-file Report 150J, scale 1:31,680, 1 sheet.

25. 1982k, Peat-resource map, Tyonek C-1 Quadrangle: Alaska Division of Geological and Geophysical Surveys Open-file Report 150K, scale 1:31,680, 1 sheet.

26. 19821, Peat-resource map, Anchorage B-8 Quadrangle: Alaska Division of Geological and Geophysical Surveys Open-file Report 150L, scale 1:31,680, 1 sheet.

27. 1982m, Peat-resource map, Tyonek B-1 Quadrangle: Alaska Division of Geological and Geophysical Surveys Open-file Report 150M, scale 1:31,680, 1 sheet.

28. Huck, R.W., and Rawlinson, S.E., 1982, Peat-resource inventory of south-central Alaska, a data report: Alaska Division of Geological and Geophysical Surveys Open-file Report 150, 88 p., scale 1:250,000, 1 sheet.

29. Lee, D.E., 1982, Photointerpretive map of the surficial geology of the north Fairbanks D-1 and south Livengood A-1 quadrangles: Alaska Division of Geological and Geophysical Surveys Open-file Report 156, scale $1: 24,000,5$ sheets.

30. March, G.D., 1982a, Photointerpretive map of the surficial geology of the Skagway B-1 Quadrangle: Alaska Division of Geological and Geophysical Surveys Open-file Report 159, scale $1: 63,360,1$ sheet.

31. 1982b, Photointerpretive map of the surficial geology of the Skagway B-2 Quadrangle: Alaska Division of Geological and Geophysical Surveys Open-file Report 161, scale $1: 63,360,1$ sheet.

32. Smith, T.E., 1981, Geology of the Clearwater Mountains, south-central Alaska: Alaska Division of Geological and Geophysical Surveys Geologic Report 60, 72 p., scale 1:63,360, 3 sheets.

33. Riehle, J.R., and Emmel, K.S., 1980, Photointerpretation map of the surficial geology, Polly Creek to McArthur River, Cook lnlet: Alaska Division of Geological and Geophysical Surveys Geologic Report 64, scale 1:63,360, 2 sheets.

34. Reger, R.D., 1981a, Geology and geologic-materials maps of Anchorage C-8 SE Quadrangle: Alaska Division of Geological and Geophysical Surveys Geologic Report 65, scale 1:25,000, 2 sheets.

35. Daniels, C.L., 1981a, Geology and geologic-materials maps of Anchorage C-7 SE Quadrangle: Alaska Division of Geological and Geophysical Surveys Geologic Report 67, scale 1:25,000, 2 sheets.

36. Reger, R.D., 1981b, Geology and geologic-materials maps of Anchorage C-8 SW Quadrangle: Alaska Division of Geological and Geophysical Surveys Geologic Report 68, scale 1:25,000, 2 sheets. 

Alaska Division of Geological and Geophysical Surveys Geologic Report 69, scale 1:25,000, 2 sheets.

38.

1981d, Geology and geologic-materials maps of Anchorage B-8 NW Quadrangle: Alaska Division of Geological and Geophysical Surveys Geologic Report 70, scale 1:25,000, 2 sheets.

39. Daniels, C.L., 1981b, Geology and geologic-materials maps of Anchorage C-7 SW Quadrangle: Alaska Division of Geological and Geophysical Surveys Geologic Report 71, scale 1:25,000, 2 sheets.

40. Bundtzen, T.K., and Laird, G.M., 1982, Geologic map of the Iditarod D-2 and eastem D-3 quadrangles: Alaska Division of Geological and Geophysical Surveys Geologic Report 72, scale $1: 63,360,1$ sheet.

41. 19838, Geologic map of the Iditarod D-1 Quadrangle: Alaska Division of Geological and Geophysical Surveys Professional Report 78, scale 1:63,360, 1 sheet.

42. 1983b, Geologic map of the McGrath D-6 Quadrangle: Alaska Division of Geological and Geophysical Surveys Professional Report 79, scale 1:63,360, I sheet.

43. Dillon, J.T., Pessel, G.H., Lueck, L.L., and Hamilton, W.B., 1987, Geologic map of the Wiseman A-4 Quadrangle, southcentral Brooks Range, Alaska: Alaska Division of Geological and Geophysical Surveys Professional Report 87, scale 1:63,360, 2 sheets.

44. Updike, R.G., and Ulery. C.A., 1984, Engineering-geology map of southwest Anchorage: Alaska Division of Geological and Geophysical Surveys Professional Report 89, scale 1:15,840, 1 sheet.

45. Bundtzen, T.K., Kline, J.T., Smith, T.E., and Albanese, M.D., 1987, Geology of the McGrath A-2 Quadrangle, Alaska: Alaska Division of Geological and Geophysical Surveys Professional Report 91, scale 1:63,360, 1 sheet.

46. Gilbert, W.G., Solie, D.N., and Kline, J.T., 1988, Geologic map of the McGrath A-3 Quadrangle, Alaska: Alaska Division of Geological and Geophysical Surveys Professional Report 92, scale $1: 63,360,2$ sheets.

47. Smith, T.E., Albanese, M.D., and Kline, G.L., 1988, Geologic map of the Healy A-2 Quadrangle, Alaska: Alaska Division of Oeological and Geophysical Surveys Professional Report 95 , scale $1: 63,360,1$ sheet.

48. Bundtzen, T.K., Laird, G.M., and Lockwood, M.S., 1988, Geologic map of the Iditarod C-3 Quadrangle, Alaska: Alaska Division of Geological and Geophysical Surveys Professional Report 96, scale 1:63,360, 1 sheet.

49. Robinson, M.S., Decker, John, Clough, J.G., Reifenstuhl, R.R., Bakke, A.A., Dillon, J.T., Combellick, R.A., and Rawlinson, S.E., 1989, Geology of the Sadlerochit and Shublik Mountains, Arctic National Wildlife Refuge, northeastern Alaska: Alaska Division of Geological and Geophysical Surveys Professional Report 100, scale 1:63,360, 1 sheet.

50. Gilbert, W.G., Solie, D.N., Kline, J.T., and Dickey, D.B., 1990, Geologic map of the McGrath B-3 Quadrangle, Alaska: Alaska Division of Geological and Geophysical Surveys Professional Report 102, scale 1:63,360, 2 sheets. 
51. Updike, R.G., and Ulery, C.A., 1983, Preliminary geologic map of the Anchorage B-6 NW (Eklutaa Lake) Quadrangle: Alaska Division of Geological and Geophysical Surveys Report of Investigations 83-8, scale 1:10,000, 2 sheets.

52. Burns, L.E., Little, T.A., Newberry, R.J., Decker, John, and Pessel, G.H., 1983, Preliminary geologic map of parts of the Anchorage C-2, C-3, D-2, and D-3 quadrangles: Alaska Division of Geological and Geophysical Surveys Report of Investigations 83-10, scale 1:25,000, 3 sheets.

53. March, G.D., 1983, Photointerpretive map of the surficial geology of the Skagway A-1 Quadrangle: Alaska Division of Geological and Geophysical Surveys Report of Investigations 83-14, scale $1: 63,360,1$ sheet.

54. Dillon, J.T., Adams, D.D., and Adler, Penny, 1983, Geologic map of the Melozitna A-4 Quadrangle: Alaska Division of Geological and Geophysical Surveys Report of Investigations 83-18, scale $1: 63,360,1$ sheet.

55. Krause, K.J., 1984, Photointerpretive map of morphological floodplain deposits and material resources, middle Kuskokwim River from Sleetmute to Kalskag: Alaska Division of Geological and Geophysical Surveys Report of Investigations 84-2, 4 p., scale 1:63,360, 5 sheets.

56. Waythomas, C.F., TenBrink, N.W., and Ritter, D.F., 1984, Surficial geology of the Livengood B-3, B-4, C-3, and C-4 quadrangles; Alaska Division of Geological and Geophysical Surveys Report of Investigations $84-6$, scale 1:63,360, 1 sheet.

57. Nye, C.J., Queen, L.D., and Motyka, R.J., 1984, Geologic map of the Makushin geothermal area, Unalaska Island: Alaska Division of Geological and Geophysical Surveys Report of Investigations 84-3, scale 1:63,360, 2 sheet.

58. Combellick, R.A., 1984a, Surficial geologic map of the Seward D-6 Quadrangle: Alaska Division of Geologic and Geophysical Surveys Report of Investigatious 84-15, scale 1:63,360, 1 sheet.

59. 1984b, Surficial geologic map of the Seward D-7 Quadrangle: Alaska Division of Geological and Geophysical Surveys Report of Investigations 84-22, scale 1:63,360, 1 sheet.

60. Hickmott, D.R., 1986a, Surficial-geologic map of the Beechey Point A-1 Quadrangle: Alaska Division of Geological and Geophysical Surveys Report of Investigations 86-6, scale 1:63,360, 1 sheet.

61. 1986b, Surficial-geologic map of the Beechey Point A-2 Quadrangle: Alaska Division of Geological and Geophysical Surveys Report of Investigations $86-7$, scale 1:63,360, 1 sheet.

62. Rawlinson, S.E., 1986a, Surficial-geologic map of the Beechey Point A-3 Quadrangle: Alaska Division of Geological and Geophysical Surveys Report of Investigations 86-8, scale 1:63,360, 1 sheet.

63. 1986b, Surficial-geologic map of the Beechey Point A-4 Quadrangle: Alaska Division of Geological and Geophysical Surveys Report of Investigations 86-9, scale 1:63,360, 1 sheet.

64. 1986c, Surficial-geologic map of the Beechey Point B-2 Quadrangle: Alaska Division of Geological and Geophysical Surveys Report of Investigations 86-10, scale 1:63,360, sheet. 
65. 1986d, Surficial-geologic map of the Beechey Point B-3 Quadrangle: Alaska Division of Geological and Geophysical Surveys Report of Investigations 86-11, scale 1:63,360, 1 sheet.

66. 1986f, Peat-resource and surficial-geologic map of the south Kenai Peninsula, Alaska: Alaska Division of Geological and Geophysical Surveys Report of Investigations 86-15, scale $1: 31,680$, I sheet.

67. March, G.D., 1987, Surficial geology and materials-resources maps of the Skagway A-2 Quadrangle, Alaska: Alaska Division of Geological and Geophysical Surveys Report of Investigations $87-6$, scale $1: 63,360,2$ sheets.

68. Combellick, R.A., and Rawlinson, S.E., 1988, Surficial geology of the Mt. Michelson C-1 Quadrangle, northeastern Alaska: Alaska Division of Goological and Geophysical Surveys Report of Investigations 88-16, scale 1:63,360, 1 sheet.

69. Updike, R.G., and Howland, M.D., 1979, Surficial goology and processes, Prudhoe Bay Oil Field, with hydrologic implications: Alaska Division of Geological and Geophysical Surveys Special Report 16, 6 p., scale $1: 12,000,17$ sheets.

70. Péwé, T.L., 1958, Pairbanks (D-2), Alaska, geology: U.S. Geological Survey Geologic Quadrangle Map GQ-110, scale 1:63,360, 1 sheet.

71. Williams, J.R., 1959, Fairbanks (D-1), Alaska, geology: U.S. Geological Survey Geologic Quadrangle Map GQ-124, scale 1:63,360, 1 sheet.

72. Coulter, H.W., and Coulter, E.B., 1961, Valdez (A-5) Quadrangle, Alaska, geology: U.S. Geological Survey Geologic Quadrangle Map GQ-142, scale 1:63,360, 1 sheet.

73. Holmes, G.W., and Péwé, T.L., 1965, Geologic map of the Mount Hayes D-3 Quadrangle, Alaska: U.S. Geological Survey Geologic Quadrangle Map GQ-366, scale 1:63,360, 1 shest.

74. Wahrhaftig, Clyde, 1970a, Geologic map of the Healy D-2 Quadrangle, Alaska: U.S. Geological Survey Geologic Quadrangle Map GQ-804, scale 1:63,360, I sheet.

75. $1970 b$, Geologic map of the Healy D-3 Quadrangle, Alaska: U.S. Geological Survey Geologic Quadrangle Map GQ-805, scale 1:63,360, 1 sheet.

76.

1970c, Geologic map of the Healy D-4 Quadrangle, Alaska: U.S. Geological Survey Geologic Quadrangle Map GQ-806, scale 1:63,360, I sheet.

77. 1970d, Geologic map of the Healy D-5 Quadrangle, Alaska: U.S. Geological Survey Geologic Quadrangle Map GQ-807, scale 1:63,360, 1 sheet.

78. 1970e, Geologic map of the Fairbanks A-2 Quadrangle, Alaska: U.S. Geological Survey Geologic Quadrangle Map GQ-808, scale 1:63,360, 1 sheet.

79. 1970f, Geologic map of the Fairbanks A-3 Quadrangle, Alaska: U.S. Geological Survey Geologic Quadrangle Map GQ-809, scale 1:63,360, 1 sheet.

80. 1970g, Geologic map of the Fairbanks A-4 Quadrangle, Alaska: U.S. Geological Survey Geologic Quadrangle Map GQ-810, scale 1:63,360, 1 sheet. 

Survey Geologic Quadrangle Map GQ-811, scale 1:63,360, 1 sheet.

82. MacKevett, E.M., Jr., 1970a, Geologic map of the McCarthy C-4 Quadrangle, Alaska: U.S. Geological Survey Geologic Quadrangle Map GQ-844, scale 1:63,360, 1 sheet.

83. 1970b, Geologic map of the McCarthy C-5 Quadrangle, Alaska: U.S. Geological Survey Geologic Quadrangle Map GQ-899, scale 1:63,360, I sheet.

84. MacKevelt, B.M., Jr., and Smith, J.G., 1972a, Geologic map of the McCarthy B-4 Quadrangle, Alaska: U.S. Geological Survey Geologic Quadrangle Map GQ-943, scale 1:63,360, 1 sheet.

85. MacKevett, E.M., Jr., 1972, Geologic map of the McCarthy C-6 Quadrangle, Alaska: U.S. Geological Survey Gedlogic Quadrangle Map GQ-979, scale 1:63,360, 1 sheet.

86. MacKevett, E.M., Jr., and Smith, J.G., 1972b, Geologic map of the McCarthy B-6 Quadrangle, Alaska: U.S. Geological Survey Geologic Quadrangle Map GQ-1035, scale 1:63,360, 1 sheet.

87. Richter, D.H., and Schmoll, H.R., 1973, Geologic map of the Nabesna C-5 Quadrangle, Alaska: U.S. Geological Survey Geologic Quadrangle Map GQ-1062, scale 1:63,360, 1 sheet.

88. Detterman, R.L., 1973, Geologic map of the Iliamna B-2 Quadrangle, Augustine Island, Alaska: U.S. Geological Survey Geologic Quadrangle Map GQ-1068, scale 1:63,360, 1 sheet.

89. MacKevett, E.M., Jr., 1974, Geologic map of the McCarthy B-5 Quadrangle, Alaska: U.S. Geological Survey Geologic Quadrangle Map GQ-1146, scale 1:63,360, 1 sheet.

90. Richter, D.H., and Smith, R.L., 1976, Geologic map of the Nabesna A-5 Quadrangle, Alaska: U.S. Geological Survey Geologic Quadrangle Map GQ-1292, scale 1:63,360, 1 sheet.

91. Richter, D.H., Matson, N.A., Ir., and Schmoll, H.R., 1976, Geologic map of the Nabesna C-4 Quadrangle, Alaska: U.S. Geological Survey Geologic Quadrangle Map GQ-1303, scale $1: 63,360,1$ sheet.

92. MacKevett, E.M., Jr., Smith, J.G., Jones, D.L., and Winkler, G.R., 1978, Geologic map of the McCarthy C-8 Quadrangle, Alaska: U.S. Geological Survey Geologic Quadrangle Map GQ1418 , scale $1: 63,360,1$ sheet.

93. Richter, D.H., Smith, R.L., Yehle, L. A., and Miller, T.P., 1979, Geologic map of the Gulkana A-2 Quadrangle, Alaska: U.S. Geological Survey Geologic Quadrangle Map GQ-1520, scale $1: 63,360$, I sheet.

94. Winkler, G.R., and MacKevett, E.M., Jr., 1981, Geologic map of the McCarthy C-7 Quadrangle, Alaska: U.S. Geological Survey Geologic Quadrangle Map GQ-1533, scale 1:63,360, 1 sheet.

95. Lowe, P.C., Richter, D.H., Smith, R.L., and Schmoll, H.R., 1982, Geologic map of the Nabesna B-5 Quadrangle, Alaska: U.S. Geological Survey Geologic Quadrangle Map GQ-1566, scale 1:63,360, 1 sheet.

96. Karlstrom, T.N.V., 1958, Ground conditions and surficial geology of the Kenai-Kasilof area, Kenai Peninsula, south-central Alaska: U.S. Geological Survey Miscellaneous Investigations Map I-269, scale 1:63,360, 1 sheet. 
97. Plafker, George, 1958, Glacial features and surficial deposits of the Malaspina District, Alaska: U.S. Geological Survey Miscellaneous Investigations Map I-271, scale 1:125,000, 1 sheet.

98. Hoare, Y.M., and Coonrad, W.L., 1959a, Geology of the Bethel Quadrangle, Alaska: U.S. Geological Survey Miscellaneous Investigations Map I-285, scale 1:250,000, 1 sheet.

99. 1959b, Geology of the Russian Mission Quadrangle, Alaska: U.S. Geological Survey Miscellaneous Investigations Map I-292, scale 1:250,000, 1 sheet.

100. Williams, J.R., 1957, Geology of the western past of the Big Delta (D-6) Quadrangle, Alaska: U.S. Geological Survey Miscellaneous Investigations Map I-297, scale 1:63,360, 1 sheet.

101. Kachedoorian, Reuben, 1960a, Engineering and surficial geology of the Nenana-Rex area, Alaska: U.S. Geological Survey Miscellaneous Investigations Map I-307, scale 1:63,360, 1 sheet.

102. 1960b, Engineering geology of the Katalla area, Alaska: U.S. Geological Survey Miscellaneous Investigations Map I-308, scale 1:63,360, 1 sheet.

103. Grantz, Arthur, 1960a, Geologic map of Talkeetna Mountains (A-2) Quadrangle, Alaska, and the contiguous area to the north and northwest: U.S. Geological Survey Miscellaneous Investigations Map I-313, scale 1:48,000, 1 sheet.

104. 1960b, Geologic map of Talkeetna Mountains (A-1) Quadrangle, and the south third of Talkeetna Mountains (B-1) Quadrangle, Alaska: U.S. Geological Survey Miscellaneous Investigations Map I-314, scale 1:48,000, 1 sheet.

105. Hoare, J.M., and Coonrad, W.L., 1961a, Geologic map of the Hagemeister Island Quadrangle, Alaska: U.S. Geological Survey Miscellaneous Investigations Map I-321, scale 1:250,000, 1 sheet.

106. Péwe, T.L., and Rivard, N.R., 1961, Geologic map and section of the Fairbanks D-3 Quadrangle, Alaska: U.S. Geological Survey Miscellaneous Investigations Map I-340, scale 1:63,360, 1 sheet.

107. Grantz, Arthur, 1961a, Geologic map and cross sections of the Anchorage (D-2) Quadrangle and northeastern mast part of the Archorage (D-3) Quadrangle, Alaska: U.S. Geological Survey Miscellaneous Investigations Map I-342, scale 1:48,000, 1 sheet.

108. $1961 b$, Geologic map of the northern two-thirds of Anchorage (D-1) Quadrangle, Alaska: U.S. Geological Survey Miscellaneous Investigations Map I-343, scale 1:48,000, 1 sheet.

109. Coulter, H.W., and Coulter, E.B., 1962, Preliminary geologic map of the Valdez-Tiekel Belt, Alaska: U.S. Geological Survey Miscellaneous Investigations Map I-356, scale 1:96,000, 1 sheet.

110. MacKevett, E.M., Jr., 1965a, Preliminary geologic map of the McCarthy B-5 Quadrangle, Alaska: U.S. Geological Survey Miscellaneous Investigations Map I-438, scale 1:63,360, 1 sheet.

111. 1965b, Preliminary geologic map of the McCarthy C-6 Quadrangle, Alaska: U.S. Geological Survey Miscellaneous Investigations Map I-444, scale 1:63,360, 1 sheet. 
112. Péwe, T.L., Wahraftig, Clyde, and Weber, F.R., 1966, Geologic map of the Fairbanks Quadrangle, Alaska: U.S. Geological Survey Miscellaneous Investigations Map I-455, scale $1: 250,000,1$ sheet.

113. Patton, W.W., Jr., and Miller, T.P., 1966, Regional geologic map of the Hughes Quadrangle, Alaska: U.S. Geological Survey Miscellaneous Investigations Map I-459, scale 1:250,000, 1 sheet.

114. Hoare, J.M., and Condon, W.H., 1966, Geologic map of the Kwiguk and Black quadrangles, western Alaska: U.S. Geological Survey Miscellaneous Investigations Map I-469, scale $1: 250,000,1$ sheet.

115. 1968, Geologic map of the Hooper Bay Quadrangle, Alaska: U.S. Geological Survey Miscellaneous Investigations Map I-523, scale 1:250,000, 1 sheet.

116. Nichols, D.R., and Yehle, L.A., 1969, Engineering geologic map of the southwestern Copper River basin, Alaska: U.S. Geological Survey Miscellaneous Investigations Map I-524, scale 1:125,000, 1 sheet.

117. Patton, W.W., Jr., Miller, T.P., and Tailleur, I.L., 1968, Regional geologic map of the Shungnak and southern part of the Ambler River quadrangles, Alaska: U.S. Geological Survey Miscellaneous Investigations Map 1-554, scale 1:250,000, 1 sheet.

118. Sainsbury, C.L., 1969, Geologic map of the Teller B-4 and southern part of the Teller C-4 quadrangles, western Seward Peninsula, Alaska: U.S. Geological Survey Miscellaneous Investigations Map I-572, scale 1:63,360, 1 sheet.

119. Weber, F.R., and Péwe, T.L., 1970, Surficial and engineering geology of the central part of the Yukon-Koyukuk Lowland, Alaska: U.S. Geological Survey Miscellaneous Investigations Map I590 , scale $1: 125,000,2$ sheets.

120. Foster, H.L., 1970, Reconnaissance geologic map of the Tanacross Quadrangle, Alaska: U.S. Geological Survey Miscellaneous Investigations Map I-593, scale 1:250,000, 1 sheet.

121. Miller, D.J., 1971, Geology of the Yakataga District, Gulf of Alaska Tertiary Province, Alaska: U.S. Geological Survey Miscelianeous Investigations Map I-610, 6 p., scale 1:125,000, 1 sheet.

122. Richter, D.H., 1971a, Reconnaissance geologic map and sections of the Nabesna A-3 Quadrangle, Alaska: U.S. Geological Survey Miscellaneous Investigations Map I-655, scale 1:63,360, 1 sheet.

123. 1971b, Reconnaissance geologic map of the Nabesna B-4 Quadrangle, Alaska: U.S. Geological Survey Miscellaneous Invastigations Map I-656, scale 1:63,360, 1 sheet.

124. Hoare, J.M., and Condon, W.H., 1971a, Geologic map of the Marshall Quadrangle, Alaska: U.S. Geological Survey Miscellaneous Investigations Map I-668, scale 1:250,000, 1 sheet.

125. 1971b, Geologic map of the St. Michael Quadrangle, Alaska: U.S. Geological Survey Miscellaneous Investigations Map I-682, scale 1:250,000, 1 sheet.

126. Sainsbury, C.L., 1972, Geologic map of the Teller Quadrangle, westera Seward Peninsula, Alaska: U.S. Geological Survey Miscellaneous Investigations Map I-685, scale 1:250,000, 1 sheet. 
127. Richter, D.H., and Jones, D.L., 1973, Reconnaissance geologic map of the Nabesna A-2 Quadrangle, Alaska: U.S. Geological Survey Miscellaneous Investigations Map I-749, scale $1: 63,360,1$ sheet.

128. Schmoll, H.R., and Dobrovolny, Bmest, 1972a, Generalized geologic map of Anchorage and vicinity, Alaska: U.S. Geological Survey Miscellaneous Investigations Map I-787-A, scale $1: 24,000,1$ sheet.

129. 1972b, Slope map of Anchorage and vicinity, Alaska: U.S. Geological Survey Miscellaneous Investigations Map I-787-B, scale 1:24,000, 1 sheet.

130. 1973c, Construction materials map of Anchorage and vicinity, Alaska: U.S. Geological Survey Miscellaneous Investigations Map I-787-C, scale 1:24,000, 1 sheel.

131. 1974, Foundation and excavation conditions map of Anchorage and vicinity, Alaska; U.S. Geological Survey Miscellaneous Investigations Map I-787-D, scale 1:24,000, I sheet.

132. Dobrovolny, Ernest, and Schmoll, H.R., 1974, Slope-stability map of Anchorage and vicinity, Alaska: U.S. Geological Survey Miscellaneous Investigations Map I-787-E, scale 1:24,000, 1 sheet.

133. Freethey, G.W., 1976, Relative permeability of surficial geologic materials, Anchorage and vicinity, Alaska: U.S. Geological Survey Miscellaneous Investigations Map I-787-F, scale $1: 24,000,1$ sheet.

134. Richter, D.H., 1973, Reconnaissance geologic map of the Nabesna A-4 Quadrangle, Alaska: U.S. Geological Survey Miscellaneous Investigations Map I-789, scale 1:63,360, 1 sheet.

135. Richter, D.H., Matson, N.A., Jr., and Schmoll, H.R., 1973, Reconnaissance geologic map of the Nabesna A-1 Quadrangle, Alaska: U.S. Geological Survey Miscellaneous Investigations Map I-807, scale 1:63,360, 1 sheet.

136. Péwe, T.L., Bell, J.W., Forbes, R.B., and Weber, F.R., 1976a, Geologic map of the Fairbanks D-2 SW Quadrangle, Alaska: U.S. Geological Survey Miscellaneous Investigations Map I-829A, scale 1:24,000, 1 sbeet.

137. Péwé, T.L., and Bell, J.W., 1974, Map showing distribution of permafrost in the Fairbanks D2 SW Quadrangle, Alaska: U.S. Geological Survey Miscellaneous Investigations Map I-829-B, scale 1:24,000, 1 sheet.

138. 1976a, Map showing groundwater conditions in the Fairbanks D-2 SW Quadrangle, Alaska: U.S. Geological Survey Miscellaneous Investigations Map I-829-C, scale 1:24,000, 1 sheet.

139. 1976b, Map showing construction materials in the Pairbanks D-2 SW Quadrangle, Alaska: U.S. Geological Survey Miscellaneous Investigations Map I-829-D, scale 1:24,000, 1 sheet.

140. 1976c, Map showing foundation conditions in the Fairbanks D-2 SW Quadrangle, Alaska: U.S. Geological Survey Miscellaneous Investigations Map I-829-E, scale 1:24,000, 1 sheet.

141. Miller, R.D., 1975, Surficial geologic map of the Juneau urban area and vicinity, Alaska: U.S. Geological Survey Miscellaneous Investigations Map I-885, scale 1:48,000, 1 sheet. 
142. Richter, D.H., 1975, Recounaissance geologic map of the Nabesaa B-3 Quadrangle, Alaska: U.S. Goological Survey Miscellaneous Investigations Map I-904, scale 1:63,360, 1 sheet.

143. Péwé, T.L., Bell, J.W., Forbes, R.B., and Weber, F.R., 1975, Geologic map of the Fairbanks D-2 NW Quadrangle, Alaska: U.S. Geological Survey Miscellaneous Investigations Map 1-907, scale $1: 24,000,1$ sheet.

144. Foster, H.L., 1976, Geologic map of the Eagle Quadrangle, Alaska: U.S. Geological Survey Miscellaneous Investigations Map 1-922, scale 1:250,000, 1 sheet.

145. Richter, D.H., 1976, Geologic map of the Nabesna Quadrangle, Alaska: U.S. Geological Survey Miscellaneous Investigations Map I-932, scale 1:250,000, 1 sheet.

146. PewE, T.L., Bell, J.W., Forbes, R.B., and Weber, F.R., 1976b, Geologic map of the Fairbanks D-2 SE Quadrangle, Alaska: U.S. Geological Survey Miscellaneous Investigations Map I-942, scale $1: 24,000,1$ sheet.

147. Péwé, T.L., Bell, J.W., Williams, J.R., and Paige, R.A., 1976, Geologic map of the Fairbanks D-1 SW Quadrangle, Alaska: U.S. Geological Survey Miscellaneous Investigations Map I-949, scale $1: 24,000,1$ sheet.

148. Péwé, T.L., Bell, J.W., Forbes, R.B., and Weber, F.R., 1976c, Geologic map of the Fairbanks D-2 NE Quadrangle, Alaska: U.S. Geological Survey Miscellaneous Investigations Map I-950, scale $1: 24,000,1$ sheet.

149. Richter, D.H., Sharp, W.N., Dutro, J.T., Jr., and Hamilton, W.B., 1977, Geologic map of parts of the Mount Hayes A-1 and A-2 quadrangles, Alaska: U.S. Geological Survey Miscellaneous Investigations Map I-1031, scale $1: 63,360,1$ sheet.

150. Patton, W.W., Ir., Miller, T.P., Chapman, R.M., and Yeend, W.E., 1978, Geologic map of the Melozitna Quadrangle, Alaska: U.S. Geological Survey Miscellaneous Investigations Map I1071, scale 1:250,000, I sheet.

151. Reed, B.L., and Nelson, S.W., 1980, Geologic map of the Talkeetna Quadrangle, Alaska: U.S. Geological Survey Miscellaneous Investigations Map I-1174, scale 1:250,000, I sheet.

152. Detterman, R.L., Miller, T.P., Yount, M.E., and Wilson, F.H., 1981, Quaternary geologic map of the Chignik and Sutwik Island quadrangles, Alaska: U.S. Geological Survey Miscellaneous Investigations Map I-1292, scale 1:250,000, 1 sheet.

153. Updike, R.G., 1986, Engineering geologic maps of the Government Hill area, Anchorage, Alaska: U.S. Geological Survey Miscellaneous Investigations Map I-1610, scale 1:4,800, 1 sheet.

154. Chapman, R.M., and Yeend, W.B., 1972, Preliminary geologic map of the northeastern part of the Tanana Quadrangle, Alaska: U.S. Geological Survey Miscellaneous Field Studies Map MF342 , scale $1: 250,000,1$ sheet.

155. Foster, H.L., 1972, Preliminary geologic map of the Eagle Quadrangle, Alaska: U.S. Geological Survey Miscellaneous Field Studies Map MF-358, scale 1:250,000, 1 sheet. 
156. Yeend, W.E., 1973a, Preliminary geologic map of a prospective transportation route from Prudhoe Bay, Alaska, to Canadian border; Part I, Beochey Point and Sagavanirktok quadrangles: U.S. Geological Survey Miscellaneous Field Studies Map MF-489, scale 1:125,000, 2 sheets.

157. 1973b, Preliminary geologic map of a prospective transportation route from Prudhoe Bay, Alaska, to Canadian border; Part II, Mt. Michelson Quadrangle, Alaska: U.S. Geological Survey Miscellaneous Field Studies Map MP-494, scale 1:125,000, 2 sheets.

158. 1973c, Pretiminary geologic map of a prospective transportation route from Prudhoe Bay, Alaska, to Canadian border; Part V, Coleen Quadrangle (north half), Alaska: U.S. Geological Survey Miscellaneous Pield Studies Map MF-502, scale 1:125,000, 2 sheets.

159. Brosge, W.P., Reiser, H.N., and Yeend, W.B., 1973, Reconnaissance geologic map of the Beaver Quadrangle, Alaska: U.S. Geological Survey Miscellaneous Field Studies Map MP-525, scale $1: 250,000,1$ sheet.

160. PéwE, T.L., and Bell, J.W., 1975a, Map showing distribution of permafrost in the Fairbanks D2 NW Quadrangle, Alaska: U.S. Geological Survey Miscellaneous Field Studies Map MF-668A, scale $1: 24,000,1$ sheet.

161. 1975b, Map showing ground water conditions in the Fairbanks D-2 NW Quadrangle, Alaska: U.S. Geological Survey Miscellaneous Field Studies Map MF-668-B, scale $1: 24,000,1$ sheet.

162. 1975c, Map showing construction materials in the Fairbanks D-2 NW Quadrangle, Alaska: U.S. Geological Survey Miscellaneous Field Studies Map MF-668-C, scale 1:24,000, 1 sheet.

163. 1975d, Map showing foundation conditions in the Fairbaoks D-2 NW Quadrangle, Alaska: U.S. Geological Survey Miscellaneous Field Studies Map MF-668-D, scale 1:24,000, 2 sheets.

164. 1975e, Map showing distribution of permafrost in the Fairbanks D-2 SE Quadrangle, Alaska: U.S. Geological Survey Miscellaneous Field Studies Map MF-669-A, scale 1:24,000, 1 sheet.

165. 1975f, Map showing ground water conditions in the Fairbanks D-2 SE Quadrangle, Alaska: U.S. Geological Survey Miscellaneous Field Studies Map MP-669-B, scale 1:24,000, 1 sheet.

166. 1975g, Map showing construction materials in the Fairbanks D-2 SE Quadrangle, Alaska: U.S. Geological Survey Miscellaneous Field Studies Map MF-669-C, scale 1:24,000, 1 sheet.

167. 1975h, Map showing foundation conditions in the Fairbanks D-2 SE Quadrangle, Alaska: U.S. Geological Survey Miscellaneous Field Studies Map MF-669-D, scale 1:24,000, 2 sheets.

168. 1975i, Map showing distribution of permafrost in the Fairbanks D-2 NE Quadrangle, Alaska: U.S. Geological Survey Miscellaneous Field Studies Map MF-670-A, scale I:24,000, 1 sheet. 
169. 1975j, Map showing ground water conditions in the Fairbanks D-2 NE Quadrangle, Alaska: U.S. Geological Survey Miscellaneous Field Studies Map MF-670-B, scale 1:24,000, 1 sheet.

170. 1975k, Map showing construction materials in the Fairbanks D-2 NE Quadrangle, Alaska: U.S. Geological Survey Miscellaneous Field Studies Map MF-670-C, scale 1:24,000, 1 sheet.

171. 19751, Map showing foundation conditions in the Fairbanks D-2 NE Quadrangle, Alaska; U.S. Geological Survey Miscellaneous Field Studies Map MF-670-D, scale 1:24,000, 2 sheets.

172.

$1975 \mathrm{~m}$, Map showing distribution of permafrost in the Fairbanks D-1 SW Quadrangle, Aluska: U.S. Geological Survey Miscellaneous Field Studies Map MF-671-A, scale $1: 24,000,1$ sheet.

173. 1975n, Map showing ground water conditions in the Fairbanks D-1 SW Quadrangle, Alaska: U.S. Geological Survey Miscellaneous Field Studies Map MF-671-B, scale 1:24,000, I sheet.

174. 19750, Map showing construction materials in the Fairbanks D-1 SW Quadrangle, Alaska: U.S. Geological Survey Miscellaneous Field Studies Map MF-671-C, scale 1:24,000, 1 sheet.

175. 1975p, Map showing foundation conditions in the Fairbanks D-1 SW Quadrangle, Alaska: U.S. Geological Survey Miscellaneous Field Studies Map MP-671-D, scale 1:24,000, 2 sheets.

176. Bartsch-Winkler, Susan, Ovenshine, A.T., and Lawson, D.E., 1975, Sedimentological maps of the Girdwood Bar, Turnagain Arm, Alaska, for July-August 1973: U.S. Geological Survey Miscellaneous Field Studies Map MF-672, scale 1:24,000, 1 sheet.

177. Weber, F.R., Foster, H.L., Keith, T.E.C., and Cantelow, A.L., 1975, Reconnaissance geologic map of the Big Delta A-1 and B-1 quadrangles, Alaska: U.S. Geological Survey Miscellaneous Field Studies Map MF-676, scale 1:63,360, 1 sheet.

178. Detterman, R.L., Plafker, George, Tysdal, R.G., and Hudson, Travis, 1976, Geology and surface features along part of the Talkeetna Segment of the Castle Mountain-Caribou fault system, Alaska: U.S. Geological Survey Miscellaneous Field Studies Map MF-738, scale 1:63,360, 1 sheet.

179. Tysdal, R.G., Hudson, Travis, and Plafker, George, 1976, Geologic map of the Cordova B-2 Quadrangle and northern part of the Cordova A-2 Quadrangle, south-central Alaska: U.S. Geological Survey Miscellaneous Field Studies Map MF-783, scale 1:63,360, 1 sheet.

180. Weber, F.R., Foster, H.L., and Keith, T.E.C., 1977, Reconnaissance geologic map of the Big Delta A-2 and A-3 quadrangles, Alaska: U.S. Geological Survey Miscellaneous Field Studies Map MF-869, scale $1: 63,360,1$ sheet.

181. Reed, B.L., and Nelson, S.W., 1977, Geologic map of the Talkeetna Quadrangle, Alaska: U.S. Geological Survey Miscellaneous Field Studies Map MF-870-A, 8cale 1:250,000, 1 sheet.

182. Nelson, S.W., and Reed, B.L., 1978, Surficial deposits of the Talkeetna Quadrangle, Alaska: U.S. Geological Survey Miscellaneous Field Studies Map MF-870-J, scale 1:250,000, 1 sheet. 
183. Hamilton, T.D., 1978a, Surficial deposits of the Chandalar Quadrangle, Alaska: U.S. Geological Survey Miscellaneous Field Studies Map MF-878-A, scale 1:250,000, 1 sheet.

184. 1978b, Surficial goologic map of the Philip Smith Mountains Quadrangle, Alaska: U.S. Geological Survey Miscellaneous Field Studies Map MF-879-A, scale 1:250,000, 1 sheet.

185. 1979a, Surficial geologic map of the Chandler Lake Quadrangle, Alaska: U.S. Geological Survey Miscellaneous Field Studies Map MF-1121, scale 1:250,000, 1 sheet.

186. 1979b, Surficial geologic map of the Wiseman Quadrangle, Alaska: U.S. Geological Survey Miscellaneous Field Studies Map MF-1122, scale 1:250,000, 1 sheet.

187. Yehle, L. A., 1980, Prelimioary surficial geologic map of the Valdez C-1 Quadrangle, Alaska: U.S. Geological Survey Miscellaneous Field Studies Map MP-1132, scale 1:63,360, 1 sheet.

188. Yehle, L.A., and Nichols, D.R., 1980, Reconnaissance map and description of the Chetaslina volcanic debris flow (new name), southeastern Copper River basin and adjacent areas, southcentral Alaska: U.S. Geological Survey Miscellaneous Field Studies Map MF-1209, scale $1: 250,000,1$ sheet.

189. Hamilton, T.D., 1980, Surficial geologic map of the Killik River Quadrangle, Alaska: U.S. Geological Survey Miscellaneous Field Studies Map MF-1234, scale 1:250,000, 1 sheet.

190. 1981, Surficial geologic map of the Survey Pass Quadrangle, Alaska: U.S. Geological Survey Miscellaneous Field Studies Map MF-1320, scale 1:250,000, 1 sheet.

191. Yehle, L.A., 1981, Preliminary surficial geologic map of the Valdez B-1 Quadrangle, Alaska: U.S. Geological Survey Miscellaneous Field Studies Map MP-1364, scale 1:63,360, 1 sheet.

192. Yehle, L.A., Schmoll, H.R., and Gardner, C.A., 1983, Preliminary surficial geologic map of the northern part of the Tyonek B-5 Quadrangle, Alaska: U.S. Geological Survey Miscellaneous Field Studies Map MF-1661-A, scale 1:31,680, 1 sheet.

193. Yeble, L.A., Schmoll, H.R., and Chleborad, A.F., 1983a, Preliminary surficial geologic map of the southwestern part of the Tyonek B-5 Quadrangle, Alaska: U.S. Geological Survey Miscellaneous Field Studies Map MF-1661-B, scale 1:31,680, 1 sheet.

194. 1983b, Preliminary surficial geologic map of the southeastem part of the Tyonek B5 Quadrangle, Alaska: U.S. Geological Survey Miscellaneous Field Studies Map MF-1661-C, scale $1: 31,680,1$ sheet.

195. Hamilton, T.D., 1984a, Surficial geologic map of the Howard Pass Quadrangle, Alaska: U.S. Geological Survey Miscellaneous Field Studies Map MF-1677, scale 1:250,000, 1 sheet.

196. 1984b, Surficial geologic map of the Ambler River Quadrangle, Alaska: U.S. Geological Survey Miscellaneous Field Studies Map MF-1678, scale 1:250,000, 1 sheet.

197. Snyder, G.L., 1959, Geology of Little Sitkin Island, Alaska: U.S. Geological Survey Bulletin $1028 \mathrm{H}$, p. $169-210$, scale $1: 20,000,1$ sheet.

198. Byers, F.M., Jr., 1959, Geology of Unonak and Bogoslof Islands, Aleutian Islands, Alaska: U.S. Geological Survey Bulletin 1028 L, p. 267-369, scale 1:63,360, 1 sheet. 
199. Gates, Olcott, Powers, H.A., Wilcox, R.E., and Schafer, J.P., 1971, Geology of the Near Islands, Alaska: U.S. Geological Survey Bulletin 1028 U, p. 709-822, scale 1:63,360, 1 sheet.

200. Miller, R.D., and Dobrovolny, Enest, 1959, Surficial geology of Anchorage and vicinity, Alaska: U.S. Geological Survey Bulletin 1093, 128 p., scale 1:63,360, 6 sheets.

201. Hopkins, D.M., 1963, Geology of the Imuruk Lake area, Seward Peninzula, Alaska; U.S, Geological Survey Bulletin 1141 C, p. C1-C101, scale 1:125,000, 1 sheet.

202. Fernald, A.T., 1964, Surficial geology of the central Kobuk River valley, northwestern Alaska: U.S. Geological Survey Bulletin 1181 K, p. K1-K31, scalo 1:250,000, 1 sheet.

203. Holmes, G.W., and Foster, H.L., 1968, Geology of the Johnson River area, Alaska: U.S. Geological Survey Bulletin 1249, 49 p., scale 1:63,360, 1 sheet.

204. Detterman, R.L., and Reed, B.L., 1973, Surficial deposits of the Miamna Quadrangle, Alaska: U.S. Geological Survey Bulletin 1368 A, p. A1-A64, scale 1:250,000, 1 sheet.

205. Smith, J,G., 1977, Geology of the Ketchikan D-1 and Bradfield Canal A-1 quadrangles, southestern Alaska: U.S. Geological Survey Bulletin 1425, 49 p., scale I:63,360, 1 sheet.

206. Waller, R.M., Feulner, A.J., and Morris, D.A., 1968, Water resources and surficial geology of the Homer area, south-central Alaska: U.S. Geological Survey Hydrologic Investigations Allas HA 187 , scale $1: 63,360,1$ sheet.

207. Post, Austin, 1975, Preliminary hydrography and historic terminal changes of Columbia Glacier, Alaska: U.S. Geologica! Survey Hydrologic Investigations Allas HA 559, scale $1: 10,000,3$ sheets.

208. Wabrhaftig, Clyde, and Black, R.F., 1958, Engineering geology along part of the Alaska Railroad: U.S. Geological Survey Professional Paper 293 B. p. 79-118, scale 1:63,360, 6 sheets.

209. Detterman, R.L., and Hartsock, J.K., 1966, Geology of the Iniskin-Tuxedni region, Alaska: U.S. Geological Survey Professional Paper 512, 78 p., scale 1:63,360, 1 sheet.

210. Sable, E.G., 1977, Geology of the western Romanzof Mountains, Brooks Range, northeastern Alaska: U.S. Geological Survey Professional Paper 897, 84 p., scale 1:63,360, 1 sheet.

211. Yehle, L.A., 1979, Reconnaissance engineering geology of the Yakutat area, Alaska, with emphasis on evaluation of earthquake and other geologic hazards: U.S. Geological Survey Professional Paper 1074, 44 p., scale 1:63,360, 1 sheet.

212. Lemke, R.W., and Yehle, L.A., 1972, Reconnaissance engineering geology of the Haines area, Alaska, with emphasis on evaluation of earthquake and other geologic hazards: U.S. Geological Survey Open-file Report 72.229, 109 p., scale 1:24,000, 2 sheets.

213. Sainsbury, C.L., Hudson, Travis, Ewing, Rodney, and Marsh, W.R., 1972a, Reconnaissance geologic map of the Nome C-2 Quadrangle, Seward Peninsula, Alaska: U.S. Geological Survey Open-file Report 72-321 (OF 506), 13 p., scale 1:63,360, 1 sheet.

214. 1972b, Reconnaissance geologic map of the Nome C-3 Quadrangle, Seward Peninsula, Alaska: U.S. Geological Survey Open-file Report 72-322 (OF 510), 9 p., scale 1:63,360, 1 sheet. 
215. Sainsbury, C.L., Smith, T.E., and Kachadoorian, Reuben, 1972, Reconnaissance geologic map of the Nome D-3 Quadrangle, Seward Peninsula, Alaska: U.S. Geological Survey Open-file Report 72-327 (OF 514), 10 p., scale 1:63,360, 1 sheet.

216. Yehle, L.A., and Lemke, R.W., 1972, Reconnajssance engireering geology of the Skagway area, Alaska, with emphasis on evaluation of earthquake and other geologic hazards: U.S. Geological Survey Open-file Report 72-454, 108 p., scale 1:9,600, 2 sheets.

217. Kachadoorian, Reuben, 1974, Geology of the Devil Canyon Dam site, Alaska: U.S, Geological Survey Open-file Report 74-40, 24 p., scale 1:24,000, 1 sheet.

218. Yehle, L.A., 1974, Reconnaissance engineering geology of Sitka and vicinity, Alaska, with emphasis on evaluation of earthquake and other geologic hazards: U.S. Geological Survey Openfile Report 74-53, 104 p., scale 1:9,600, 3 sbeets.

219. Plafker, George, 1974, Preliminary geologic map of Kayak and Wingham islands, Alaska: U.S. Geological Survey Open-file Report 74-82, scale 1:31,680, 1 sheet.

220. Lemke, R.W., 1975, Reconnaissance engineering geologic map of the Ketchikan area, Alaska, with emphasis on evaluation of earthquake and other geologic hazards: U.S. Geological Survey Open-file Report 75-250, 110 p., scale 1:4,800, I sheet.

221. Yeble, L.A., 1975, Preliminary report on the reconnaissance engineering geology of the Yakutat area, Alaska, with emphasis on evaluation of earthquake and other geologic hazards: U.S. Geological Survey Open-file Report 75-529, 136 p., scale 1:63,360, 2 sheets.

222. Hopkins, D.M., 1977, Coastal processes and coastal erosional hazards to the Cape Krusenstern archaeological site: U.S. Geological Survey Open-file Report 77-32, 14 p., scale 1:253,440, 1 sheet.

223. Foster, H.L., Dusel-Bacon, Cynthia, and Weber, F.R., 1977, Reconnaissance geologic map of the Big Delta C-4 Quadrangle, Alaska: U.S. Geological Survey Open-file Report 77-262, scale $1: 63,360,1$ sheet.

224. Yehle, L.A., 1977, Reconnaissance engineering geology of the Metlakatla area, Annette Island, Alaska, with emphasis on evaluation of earthquake and other geologic hazards: U.S. Geological Survey Open-file Report 77-272, 93 p., scale 1:9,600 and 1:250,000, 4 sheets.

225. Williams, J.R., Yeend, W.E., Carter, L.D., and Hamilton, T.D., 1977, Preliminary surficial deposits map, National Petroleum Reserve, Alaska: U.S. Geological Survey Open-file Report 77-868, scale 1:500,000, 2 sheets.

226. Reiser, H.N., Brosge, W.P., Detterman, R.L., and Dutro, J.T., Jr., 1978, Geologic map of the Demarcation Point Quadrangle, Alaska: U.S. Geological Survey Open-file Report 78-526, scale $1: 200,000,1$ sheet.

227. Weber, F.R., Foster, H.L., Keith, T.E.C., and Dusel-Bacon, Cynthia, 1978, Preliminary geologic map of the Big Delta Quadrangle, Alaska: U.S. Geological Survey Open-file Report 78529 A, scale 1:250,000, 1 sheet.

228. Yehle, L.A., 1978, Reconnaissance engineering geology of the Petersburg area, southeastern Alaska, with emphasis on geologic hazards: U.S. Geological Survey Open-file Report 78-675, 92 p., scale 1:9,600 and 1:250,000, 2 sheets. 
229. Carter, L.D., and Galloway, J.P., 1978, Preliminary engineering geologic maps of the proposed natural gas pipeline route in the Tanana River valley, Alaska: U.S. Geological Survey Open-file Report 78-794, 26 p., scale 1:125,000, 3 sheets.

230. Schmoll, H.R., Dobrovolny, Ernest, and Gardner, C.A., 1980, Preliminary geologic map of the middle part of the Eagle River valley, Municipality of Anchorage, Alaska: U.S. Geological Survey Open-file Report 80-890, 12 p., scale 1:25,000, 1 sheet.

231. Williams, J.R., and Johnson, K.M., 1980, Map and description of late Tertiary and Quaternary deposits, Valdez Quadrangle, Alaska: U.S. Geological Survey Open-file Report 80-892 C, scale 1:250,000, 2 sheets.

232. Schmoll, H.R., Yehle, L.A., and Gardner, C.A., 1981, Preliminary geologic map of the Congahbuna area, Cook Inlet region, Alaska: U.S. Geological Survey Open-file Report 81-429, 9 p., scale 1:63,360, 1 sheet.

233. Scbmoll, H.R., Dobrovolny, Emest, and Gardner, C.A., 1981, Preliminary geologic map of Fire Island, Municipality of Anchorage, Alaska: U.S. Geological Survey Open-file Report 81 552,5 p., scale $1: 25,000,1$ sheet.

234. Wirkler, G.R., and Plafker, George, 1981, Geologic map and cross sections of the Cordova and Middleton Island Quadrangles, southern Alaska: U.S. Geological Survey Open-file Report 811164,26 p., scale 1:250,000, 1 sbeet.

235. Schmoll, H.R., and Emanuel, R.P., 1981, Generalized geologic map and hydrologic properties of the Potter Creek area, Municipality of Anchorage, Alaska: U.S. Geological Survey Open-file Report 81-1168, scale 1:25,000, 1 sheet.

236. Curtis, S.M., Ellersieck, Inyo, Mayfield, C.F., and Tailleur, I.L., 1982, Reconnaissance geologic map of soutbwestern Misheguk Mountain Quadrangle, Alaska: U.S. Geological Survey Open-file Report 82-611, 43 p., scals 1:63,360, 2 sheets.

237. Ellersieck, Inyo, Curtis, S.M., Mayfield, C.F., and Tailleur, I.L., 1982, Reconnaissance geologic map of south-central Misheguk Mountain Quadrangle, Alaska: U.S. Geological Survey Open-file Report 82-612, 38 p., scale 1:63,360, 2 sheets.

238. Mayfield, C.F., Curtis, S.M., Ellersieck, Inyo, and Tailleur, I.L., 1982, Reconnaissance geologic map of southeastern Misheguk Mountain Quadrangle, Alaska: U.S. Geological Survey Open-file Report 82-613, 40 p., scale 1:63,360, 2 sheets.

239. Chapman, R.M., Yeend, W.E., Brosge, W.P., and Reiser, H.N., 1982, Reconnaissance geologic map of the Tanana Quadrangle, Alaska: U.S. Geological Survey Open-file Report 82-734, 20 p., scale $1: 250,000,1$ sheet.

240. Mayfield, C.F., Curtis, S.M., Ellersieck, Inyo, and Tailleur, I.L., 1983, Raconnaissance genlogic map of the De Long Mountains A3, B3, and parts of A4, B4 quadrangles, Alaska: U.S. Geological Survey Open-file Report 83-183, 60 p., scale 1:63,360, 2 sheots.

241. Ellersieck, Inyo, Curtis, S.M., Mayfield, C.P., and Tailleur, I.L., 1983, Reconnaissance geologic map of the De Long Mountains A2, B2, and part of C2 quadrangles, Alaska: U.S. Geological Survey Open-file Report 83-184, 54 p., scale 1:63,360, 2 sheets. 
242. Curtis, S.M., Ellersieck, Inyo, Mayfield, C.F., and Tailleur, I.L., 1983, Reconasissance geologic map of the De Long Mountains A1, BI, and part of C1 quadrangles, Alaska: U.S. Geological Survey Open-file Report 83-185, 54 p., scale 1:63,360, 2 sheets.

243. Yeend, W.E., 1983, Engineering-geologic maps of northern Alaska, Lookout Ridge Quadrangle: U.S. Geological Survey Open-file Report 83-279, scale 1:250,000, 2 sheets.

244. Williams, J.R., 1983a, Engineering-geologic maps of northern Alaska, Meade River Quadrangle: U.S. Geological Survey Open-file Report 83-294, 32 p., scale 1:250,000, 1 sheet.

245. 1983b, Engineering-geologic maps of northern Alaska, Wainwright Quadrangle: U.S. Geological Survey Open-file Report 83-457, 30 p., scale 1:250,000, 1 sheet.

246. Schmoll, H.R., and Emanuel, R.P., 1983, Geologic materials and hydrogeologic characteristics in the Fire Lakes-Eklutoa area, Anchorage, Alaska: U.S. Geological Survey Open-file Report $83-479$, scale 1:25,000, 1 sheet.

247. Carter, L.D., 1983, Engineering geologic maps of northern Alaska, Teshekpuk Quadrangle: U.S. Geological Survey Open-file Report 83-634, scale 1:250,000, 1 sheet.

248. Koster, E. A., Galloway, J.P., and Pronk, Toon, 1984, Photo-interpretation map of surficial deposits and landforms of the Nogahabara sand dunes and part of the Koyukuk Lowland, Alaska: U.S. Geological Survey Open-file Report 84-10, scale 1:60,390, 1 sheet.

249. Mayfield, C.F., Ellersieck, Inyo, and Tailleur, I.L., 1984, Reconnaissance geologic map of the Noatak C5, D5, D6, and D7 quadrangles, Alaska: U.S. Geological Survey Open-file Report 84396,27 p., scale $1: 63,360,1$ sheet.

250. Hamilton, T.D., and Bauer, D.P., 1984, Engineering-geologic maps of northern Alaska, Howard Pass Quadrangle: U.S. Geological Survey Open-file Roport 84-401, seale 1:250,000, 1 sheet.

251. Yeend, W.E., 1984, Engineering-geologic maps of northern Alasks, Utukok River Quadragle: U.S. Geological Survey Open-file Report 84-682, scale 1:250,000, 2 sheets.

252. Williams, J.R., 1985, Engineering-geologic map of southwestern Copper River basin and upper Matanuska River valley, Alaska: U.S. Geological Survey Open-file Report 85-143, scale $1: 125,000,2$ sheets.

253. Chapman, R.M., Patton, W.W., Jr., and Moll, E.J., 1985, Reconnaissance geologic map of the Ophir Quadrangle, Alaska: U.S. Geological Survey Open-file Report 85-203, 19 p., scale $1: 250,000,1$ sheet.

254. Carter, L.D., and Galloway, J.P., 1985, Engineering-geologic maps of northern Alaska, Harrison Bay Quadrangle: U.S. Geological Survey Open-file Report 85-256, 49 p., scale 1:250,000, 2 sheets.

255. Till, A.B., Dumoulin, J.A., Gamble, B.M., Kaufman, D.S., and Carrol, P.I., 1986, Preliminary geologic map and fossil data, Solomon, Bendeleben, and southern Kotzebue quadrangles, Seward Peninsula, Alaska: U.S. Geological Survey Open-file Report 86-276, 60 p., scale $1: 250,000,3$ sheets. 
256. Richter, D.H., Ratte, J.C., Schmoll, H.R., Leeman, W.P., Smith, J.G., and Yehle, L.A., 1989, Geologic map of the Gulkana B-1 Quadrangle, soutb central Alaska: U.S. Geological Survey Geologic Quadrangle Map GQ 1655, scale 1:63,360, 1 sheet.

257. Plafker, George, Lull, J.S., Nokleberg, W.J., Pessel, G.H., Wallace, W.K., and Winkler, G.R., 1989, Geologic map of the Valdez A-4, B-3, B-4, C-3, C-4 and D-4 quadrangles, northern Chugach Mountains and southern Copper River basin, Alaska: U.S. Geological Survey Open-file Report 89-569, scale 1:63,360, 1 sheet.

258. Yehle, L.A., and Schmoll, H.R., 1989, Surficial geologic map of the Anchorage B-7 SW Quadrangle, Alaska: U.S. Geological Survey Open-file Report 89-318, 34 p., scale 1:25,000, 2 sheets.

259. 1988, Surficial geologic map of the Anchorage B-7 SE Quadrangle, Alaska: U.S. Geological Survey Open-file Report 88-381, 20 p., scale 1:25,000, 2 sheets.

260. Carter, L.D., and Galloway, J.P., 1986, Engineering-geologic maps of northern Alaska, Umiat Quadrangle: U.S. Geological Survey Open-file Report 86-335, 16 p., scale 1:250,000, 2 sheets.

261. 1988, Engineering-geologic maps of northern Alaska, Ikpikpuk River Quadrangle: U.S. Geological Survey Open-file Report 88-375, 19 p., scale 1:250,000, 2 sheets.

262. Reihle, J.R., Detterman, R.L., Yount, M.E., and Miller, J.W., 1987, Preliminary geologic map of the Mt Katmai Quadrangle and portions of the Afognak and Naknek quadrangles, Alaska: U.S. Geological Survey Open-file Report 87-593, scale 1:250,000, 1 sheet.

263. Yehle, L.A., and Schmoll, H.R., 1987b, Surficial geologic map of the Anchorage B-7 NE Quadrangle, Alaska: U.S. Geological Survey Open-file Report 87-416, 20 p., scale 1:25,000, 2 sheets.

264. 1987a, Surficial geologic map of the Anchorage B-7 NW Quadrangle, Alaska: U.S. Geological Survey Open-file Report 87-168, 12 p., scale 1:25,000, 2 sheets.

265. Reed, J.C., Jr., 1961, Geology of the Mount McKinley Quadrangle, Alaska: U.S. Geological Survey Bulletin 1108 A, p. A1-A36, scale 1:250,000, 1 sheet.

266. Kachadoorian, Reuben, Sainsbury, C.L., and Hummel, C.L., 1975, Analyses of stream sediment samples from the Teller A-3 Quadrangle, Seward Peninsula, west-central Alaska: U.S. Geological Survey Open-file Report 75-349, 7 p., scale 1:63,360, 1 sheet.

267. Kuhry-Helms, K.F., Koster, E.A., and Galloway, J.P., 1985, Photo-interpretation map of surficial deposits and landforms of the Kobuk Sand Dunes and part of the Kobuk Lowland, Alaska: U.S. Geological Survey Open-file Report 85-242, scale 1:63,360, 1 sheet.

268. Rawlinson, S.E., 19860, Surficial-geologic map of the Beechey Point B-4 Quadrangle, Alaska: Alaska Division of Geological and Geophysical Surveys Report of Investigations 86-12, scale $1: 63,360,1$ sheet.

269. Kachadoorian, Reuben, Hopkins, D.M., and Nichols, D.R., 1954, A preliminary report of geologic factors affecting higbway construction in the area between the Susitna-Maclaren Rivers: U.S. Geological Survey Open-file Report 54-137 (OF 92), 73 p., scale 1:40,000, 1 sheet. 
270. Kachadoorian, Reuben, and Péwé, T.L., 1955, Engineering geology of the southern half of the Mount Hayes A-5 Quadrangle: U.S. Geological Survey Open-file Report 55-78 (OF 110), 27 p., scale $1: 40,000,1$ sheet.

271. Péwé, T.L., Hopkins, D.M., and Lachenbruch, A.J., 1959, Engineering geology bearing on harbor site selection along the northwest cosst of Alaska from Nome to Point Barrow: U.S. Geological Survey Open-file Report 59-94 (OF 173), 57 p., scale 1:63,360 and 1:250,000, 5 sheets.

272. Kachadoorian, Reuben, 1960c, Engineering geology bearing on harbor site selection along the Gulf of Alaska from Port Whitshed to Cape Yakataga, Alaska: U.S. Geological Survey Openfile Report 60-85 (OF 188), 32 p., scale 1:40,000, 1 sheet.

273. Miller, D.J., 1961a, Geology of the Katalla District, Gulf of Alaska Tertiary Province, Alaska: U.S. Geological Survey Open-file Report 61-99 (OF 206), scale 1:96,000, 2 sheets.

274. $1961 \mathrm{~b}$, Geology of the Lituya District, Gulf of Alaska Tertiary Province, Alaska: U.S. Geological Survey Open-file Report 61-100 (OR 210), scale 1:96,000, 1 sheet.

275. Weber, F.R., 1961, Reconnaissance engineering geology for selection of a highway route from Talkeetna to McGrath, Alaska: U.S. Geological Survey Open-file Report 61-169 (OF 224), scale $1: 250,000,2$ sheets.

276. Brabb, E.E., and Churkin, Michael, Ir., 1965, Preliminary geologic map of the Eagle D-1 Quadrangle, Alaska: U.S. Geological Survey Open-file Report 65-20 (OF 249), scale 1:63,360, 2 sheets.

277. Grantz, Arthur, 1965, Geologic nuap and cross-sections of the Neichina area, southcentral Alaska: U.S. Geological Survey Open-file Report 65-65 (OF 255), scale 1:63,360, 4 sheets.

278. Clark, S.H.B., and Foster, H.L., 1969, Preliminary geologic map of the Eagle D-2 and D-3 quadrangles, Alaska: U.S. Geological Survey Open-file Report 69-43 (OF 349), scale 1:63,360, I sheet.

279. Chapman, R.M., Weber, F.R., and Taber, Bond, 1971, Preliminary geologic map of the Livengood Quadrangle, Alaska: U.S. Geological Survey Open-file Report 71-66 (OF 483), scale 1:250,000, 2 sheets.

280. Kachadoorian, Reuben, 1971c, Preliminary engineering geologic maps of the proposed TransAlaska Pipeline route, Wiseman and Chandalar quadrangles: U.S. Geological Survey Open-file Report 71-166 (OF 486), scale 1:125,000, 2 sheets.

281. 1971a, Preliminary engineering geologic maps of the proposed Trans-Alaska Pipeline route, Bettles and Beaver quadrangles: U.S. Geological Survey Open-file Report 71164 (OF 487), scale $1: 125,000,2$ sheets.

282. Weber, F.R., 1971a, Preliminary engineering geologic maps of the proposed Trans-Alaska Pipeline route, Fairbanks and Big Delta quadrangles: U.S. Geological Survey Open-file Report 71-317 (OF 488), scale 1:125,000, 2 sheets.

283. Kachadoorian, Reuben, 1971b, Preliminary engineering geologic maps of the proposed TransAlaska Pipeline route, Tanana and Livengood quadrangles: U.S. Geological Survey Open-file Report 71-165 (OF 489), scale 1:125,000, 2 sheets. 
284. Ferrians, O.J., 1971a, Prelimizary engineering geologic maps of the proposed Trans-Alaska Pipeline route, Beechey Point and Sagavanirktok quadrangles: U.S. Geological Survey Open-file Report 71-101 (OF 491), scale 1:125,000, 2 sheets.

285. 1971b, Preliminary engineering geologic maps of the proposed Trans-Alaska Pipeline route, Philip Smith Mountains Quadrangle: U.S. Geological Survey Open-file Report 71-103 (OF 492), scale 1:125,000, 2 sheets.

286. Weber, F.R., 197 Ib, Proliminary engineering geologic maps of the proposed Trans-Alaska Pipeline route, Mt. Hayes Quadrangle: U.S. Geological Survey Open-file Report 71-318 (OF 493), scale $1: 125,000,2$ sheets.

287. Ferrians, O.J., 1971C, Preliminary ongineering geologic maps of the proposed Trans-Alaska Pipeline route, Gulkana Quadrangle: U.S. Geological Survey Open-file Report 71-102 (OF 494), scale $1: 125,000,2$ sheets.

288. 1971d, Preliminary engineering geologic maps of the proposed Trans-Alaska Pipeline route, Valdez Quadrangle: U.S. Geological Survey Open-file Report 71-104 (OF 495), scale $1: 125,000,2$ sheets.

289. Schmoll, H.R., and Dobrovolny, Emest, 1971, Generalized geologic map of the Eagle RiverBirchwood area, greater Anchorage Borough area, Alaska: U.S. Geological Survey Open-file Report 71-248 (OF 503), scale 1:63,360, 1 sheet.

290. Sainsbury, C.L., Hudson, Travis, Ewing, Rodney, and Marsh, W.R., 1972c, Reconosissance geologic maps of the Solomon D-5 and C-S quadrangles, Seward Peninsula, Alaska: U.S. Geological Survey Open-file Report 72-323 (OF 511), 12 p., scale 1:63,360, 1 sheet.

291. Miller, T.P., Grybeck, D.J., Elliott, R.L., and Hudson, Travis, 1972, Preliminary geologic map of the eastern Solomon and soutbeastera Bendeleben quadraugles, eastern Seward Peninsula, Alaska: U.S. Geological Survey Open-file Report 72-256 (OF 537), 11 p., scale $1: 250,000,1$ sheet.

292. Sainsbury, C.L., Hummel, C.L., and Hudson, Travis, 1972, Reconnaissance geologic map of the Nome Quadrangle, Seward Peninsula, Alaska: U.S. Geological Survey Open-file Report 72 326 (OF 543), 28 p., scale 1:250,000, 1 sheet.

293. Sainsbury, C.L., Hudson, Travis, Ewing, Rodney, and Marsh, W.R., 1972d, Reconnaissance geologic map of the west half of the Solomon Quadrangle, Alaska; U.S. Geological Survey Open-file Report 72-324 (OF 544), 10 p. scale 1:250,000, 1 sheet.

294. Gilbert, W.G., Bundtzen, T.K., Kline, J.T., and Laird, G.M., 1990, Preliminary geology and geochemistry of the southwest part of the Lime Hills D-4 Quadrangle, Alaska: Alaska Division of Geological and Geophysical Surveys Report of Investigations 90-6, scale 1:63,360, 1 sheet.

295. Solie, D.N., Gilbert, W.G., Harris, E.E., Kline, J.T., Liss, S.A., and Robinson, M.S., 1991, Preliminary geologic map of the Tyonek D- 6 and eastern Tyonek D-7 quadrangles, Alaska: Alaska Division of Geological and Geophysical Surveys Public-data File 91-10, 16 p., scale $1: 40,000,1$ sheet.

296. Combellick, R.A., 1989, Surficial geology of the U.S. Coast Guard Reservation, Kodiak, Alaska: Alaska Division of Geological and Geophysical Surveys Public-data File 89-8B, 56 p.. scale $1: 6,000$ and $1: 12,000,7$ sheets. 
297. Rawlinson, S.B., 1990, Surficial geology and morphology of the Alaskan central Arctic Coastal Plain: Alaska Division of Geological and Geophysical Surveys Public-data File 90-27, 311 p., scale $1: 63,360,6$ sheets.

298. Waythomas, C.F., 1991, Surficial geologic maps of the Sagavanirktok A-1, A-2, and B-2 quadrangles, northeastern Brooks Range, Alaska: Alaska Division of Geological and Geophysical Surveys Public-data File 91-21A, scale 1:63,360, 3 sheets.

299. Reiser, H.N., Brosgé, W.P., Dutro, J.T., Jr., and Detterman, R.L., 1971, Preliminary geologic map, Mt. Michelson Quadrangle, Alaska: U.S. Geological Survey Open-file Report 71237 (OP 490), scale 1:200,000, 2 sheets.

300. Nelson, S.W., and Grybeck, D.J., 1980, Geologic map of the Survey Pass Quadrangle, Brooks Range, Alaska: U.S. Geological Survey Miscellaneous Field Studies MF-1176-A, scale 1:250,000, 2 sheets.

301. Patton, W.W., Jr., Moll, E.J., Dutro, J.T., Jr., Silberman, M.L., and Chapman, R.M., 1980, Preliminary geologic map of the Medfra Quadrangle, Alaska: U.S. Geological Survey Open-file Report 80-811 A, scale I:250,000, 1 sheet.

302. Patton, W.W., Jr., 1966, Regional geology of the Kateel River Quadrangle, Alaska: U.S. Geological Survey Miscellaneous Geologic Investigations I-437, scale 1:250,000, 1 sheet.

303. Brew, D.E., and Ford, A.B., 1977, Preliminary geologic and metamorphic-isograd map of the Juneau B-1 Quadrangle, Alaska: U.S. Geological Survey Miscellaneous Field Studies MF-846, scale $1: 31,680,1$ sheet.

304. McLean, Hugh, Engelhardt, C.L., and Howell, D.G., 1978, Reconnaissance geologic map of the Cold Bay and False Pass quadrangles, Alaska: U.S. Geological Survey Open-file Report 78323, scale $1: 250,000,1$ sheet.

305. Winkler, G.R., 1973, Geologic map of the Cordova A-7 and A-8, B-6, B-7, and B-8 quadrangles, Hinchinbrook Island, Alaska: U.S. Geological Survey Miscellaneous Field Studies MF531, scale $1: 63,360,1$ sheet.

306. Brabb, E.B., and Churkin, Michael, Jr., 1969, Geologic map of the Charley River Quadrangle, east-central Alaska: U.S. Geological Survey Miscellaneous Investigations 1-573, scale $1: 250,000,1$ sheet.

307. Brabb, E.E., 1970, Preliminary geologic map of the Black River Quadrangle, east-central Alaska: U.S. Geological Survey Miscellaneous Investigations [-601, scale 1:250,000, 1 sheet.

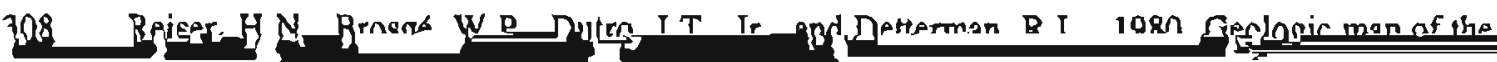


311. Nakleberg, W.J., Albert, N.R.D., Bond, G.C., Herzon, P.L., Miyaoka, R.T., Nelson, W.H., Richter, D.H., Smith, T.B., Stout, J.H., Yeend, W.E., and Zehner, R.E., 1982, Geologic map of the southern part of the Mount Hayes Quadrangle, Alaska: U.S. Geological Survey Open-file Report 82-52, 26 p., scale 1:250,000, 1 sheet.

312. Chaparan, R.M., Yeend, W.E., and Patton, W.W., Jr., 1975, Preliminary reconnaissance geologic map of the western half of Kantishna River Quadrangle, Alaska: U.S. Geological Survey Open-file Report 75-351, scale 1:250,000, 1 sheet.

313. Chapman, R.M., Yeend, W.E., Brosgé, W.P., and Reiser, H.N., 1975, Preliminary geologic map of the Tanana and northeast part of the Kantishna River quadrangles, Alaska: U.S. Geological Survey Open-file Report 75-337, scale 1:250,000, 1 sheet.

314. Yeend, W.E., and Brosgé, W.P., 1973b, Preliminary geologic map of a prospective transportation route from Prudhoe Bay, Alaska, to Canadian border; Part IV, Arctic and Table Mtn. quadrangles: U.S. Geological Survey Miscellaneous Field Studies MF-522, scale 1:125,000, 2 sheets.

315. 1973a, Preliminary geologic map of a prospective transportation route from Prudhoe Bay, Alaska, to Canadian border; Part III, Arctic Quadrangle (north half), Alaska: U.S. Geological Survey Miscellaneous Field Studies MF-501, scale 1:125,000, 2 sheets.

316. Mayfield, C.F., Ellersieck, Inyo, and Tailleur, I.L., 1987, Reconnaissance geologic map of the Noatak C5, D5, D6, and D7 quadrangles, Alaska: U.S. Geological Survey Miscellaneous Investigations I 1814, scale 1:63,360, 1 sheet.

317. Detterman, R.L., Wilson, F.H., Yount, M.E., and Miller, T.P., 1987, Quaternary geologic map of the Ugashik, Bristol Bay, and western part of Karluk quadrangies, Alaska: U.S. Geological Survey Miscellaneous Investigations I-1801, scale 1:250,000, 1 sheet.

318. Detterman, R.L., Plafker, George, Hudson, Travis, Tysdal, R.G., and Pavoni, Nazario, 1974, Surface geology and Holocene breaks along the Susitna segment of the Castle Mountain Fault, Alaska: U.S. Geological Survey Miscellanous Field Studies MF-618, scale 1:24,000, 1 sheet.

319. Schmoll, H.R., and Yehle, L.A., 1987, Surficial geologic map of the northwestern quarter of the Tyonek A-4 Quadrangle, south-central Alaska: U.S. Geological Survey Miscellaneous Field Studies MF-1934, scale 1:31,680, 1 sheet.

320. Barnwell, W.W., and Boning, C.W., 1968, Water resources and surficial geology of the Mendenhall valley, Alaska: U.S. Geological Survoy Hydrologic Investigations Allas HA-259, 6 p., scale 1:31,680 and $1: 63,360,1$ sheet.

321. Miller, R.D., 1972, Surficial geology of the Juneau urban area and vicinity, Alaska, with emphasis on earthquake and other geologic hazards: U.S. Geological Survey Open-file Report 72-255, 108 p., 2 sheets.

322. Pavlis, T.L., 1986, Geologic map of the Anchorage C-5 Quadrangle, Alaska: Alaska Division of Geological and Geophysical Surveys Public-data File 86-7, 57 p., scale 1:63,360, 1 sheet.

323. Cameron, C.C., Malterer, T.J., Rawlinson, S.E., and Hardy, S. B., 1981a, Surficial geology and peat resources map of the Houston 8rea, Susitna valley, Alaska: U.S. Geological Survey Open-file Report 81-1301, scale 1:15,840, 2 sheots. 
324. 1981b, Surficial geology and peat resources map of the Rogers Creek area, Susitng Valley, Alaska: U.S. Geological Survey Open-file Report 81-1302, scale 1:15,840, 3 sheets.

325. Pation, W.W., Jr., Miller, T.P., Chapman, R.M., and Yeend, W.E., 1977, Regional geologic map of the Melozitna Quadrangle, Alaska: U.S. Goological Survey Open-file Report 77-147, scale $1: 250,000,1$ sheet.

326. Williams, J.R., and Carter, L.D., 1984, Engineering-geologic maps of northern Alaska, Barrow Quadrangle: U.S. Geological Survey Open-file Report 84-124, 39 p., scale 1:250,000, 2 sheets.

327. Sainsbury, C.L., Kachadoorian, Reuben, Hudson, Travis, Smith, T.E., Richards, T.R., and Todd, W.E., 1969, Reconnaissance geologic maps and sample data, Teller A-1, A-2, A-3, B-1, B-2, B-3, C-1 and Bendeleben A-6, B-6, C-6, D-5, and D-6 Quadrangles, Seward Peninsula, Alaska: U.S. Geological Survey Open-file Report 69-236 (OF 377), 60 p., scale 1:63,360, 13 sheets.

328. Dillon. J.T., Reifenstuhl, R.R., Bakke, A.A., and Adams, D.D., 1990, Geologic map of the Wiseman A-1 Quadrangle, southcentral Brooks Range, Alaska: Alaska Division of Geological and Geophysical Surveys Professional Report 98, scale 1:63,360, 1 sheet.

329. Dillon, J.T., and Reifenstuhl, R.R., 1990, Geologic map of the Wiseman B-1 Quadrangle, southcentral Brooks Range, Alaska: Alaska Division of Geological and Geophysical Surveys Professional Report 101, scale 1:63,360, 1 sheet.

330. Péwé, T.L., and Holmes, G.W., 1964, Geology of the Mt. Hayes D-4 Quadrangle, Alaska: U.S, Geological Survey Miscellaneous Investigations Map I-394, scale 1:63,360, 2 sheets.

331. MacKevett, E.M., Jr., Berg, H.C., Plafker, George, and Jones, D.L., 1964, Preliminary geologic map of the McCartby C-4 Quadrangle, Alaska: U.S. Geological Survey Miscellaneous Investigations Map I-423, scale 1:63,360, 1 sheet.

\section{ALPHABETICAL LISTING}

320. Barnwell, W.W., and Boning, C.W., 1968, Water resources and surficial geology of the Mendenhall valley, Alaska: U.S. Geological Survey Hydrologic Investigations Atlas HA-259, 6 p., scale 1:31,680 and 1:63,360, 1 sheet.

176. Bartsch-Winkler, Susan, Ovenshine, A.T., and Lawson, D.E., 1975, Sedimentological maps of the Girdwood Bar, Tumagain Arm, Alaska, for July-August 1973: U.S. Geological Survey Miscellaneous Field Studies Map MF -672, scale 1:24,000, 1 sheet.

307. Brabb, B.B., 1970, Preliminary geologic map of the Black River Quadrangle, east-central Alaska: U.S. Geological Survey Miscellaneous Investigations [-601, scale 1:250,000, 1 sheet.

276. Brabb, E.E., and Churkin, Michael, Jr., 1965, Preliminary geologic map of the Eagle D-1 Quadrangle, Alaska: U.S. Geological Survey Open-file Report 65-20 (OF 249), scale 1:63,360, 2 sheets.

306. 1969, Geologic map of the Charley River Quadrangle, enst-central Alaska: U.S.

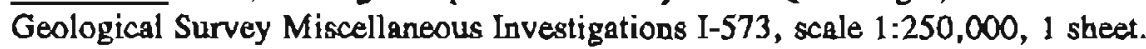


303. Brew, D.E., and Ford, A.B., 1977, Preliminary geologic and metamorphic-isograd map of the Juneau B-1 Quadrangle, Alaska: U.S. Geological Survey Miscellaneous Field Studies MF-846, scale $1: 31,680,1$ sheet.

159. Brosge, W.P., Reiser, H.N., and Yeend, W.E., 1973, Reconnaissance geologic map of the Beaver Quadrangle, Alaska: U.S. Geological Survey Miscellaneous Field Studies Map MF-525, scale 1:250,000, 1 sheet.

2. Buffler, R.T., 1976, Geologic map of south Augustine Island, lower Cook Inlet: Alaska Division of Geological and Geophysical Surveys Open-file Report 96, 3 p., scale 1:24,000, 1 sheet.

45. Bundtzen, T.K., Kline, J.T., Smith, T.E., and Albanese, M.D., 1987, Geology of the McGrath A-2 Quadrangle, Alaska: Alaska Division of Goological and Geophysical Surveys Professional Report 91, scale 1:63,360, 1 sheet.

13. Bundtzen, T.K., and Laird, G.M., 1980, Preliminary geology of the McGrath-Upper Innoko River area, western interior Alaska: Alaska Division of Geological and Geophysical Surveys Open-file Report 134, 36 p., scale 1:63,360, 2 sheets.

40. 1982, Geologic map of the Iditarod D-2 and eastern D-3 quadrangles: Alaska Division of Geological and Geophysical Surveys Geologic Report 72, scale 1:63,360, 1 sheet.

41. 1983a, Geologic map of the Iditarod D-1 Quadrangle: Alaska Division of Geological and Geophysical Surveys Professional Report 78, scale 1:63,360, 1 sheet.

42. 1983b, Geologic map of the McGrath D-6 Quadrangle: Alaska Division of Geological and Geophysical Surveys Professional Report 79, scale 1:63,360, 1 sheet.

48. Bundtzen, T.K., Laird, G.M., and Lockwood, M.S., 1988, Geologic map of the Iditarod C-3 Quadrangle, Alaska: Alaska Division of Geological and Geopbysical Surveys Professional Report 96, scale 1:63,360, 1 sheet.

52. Burns, L.E., Little, T.A., Newberry, R.J., Decker, John, and Pessel, G.H., 1983, Preliminary geologic map of parts of the Anchorage C-2, C-3, D-2, and D-3 quadrangles: Alaska Division of Geological and Geophysical Surveys Report of Investigations 83-10, scale 1:25,000, 3 sheets.

198. Byers, F.M., Jr., 1959, Geology of Umnak and Bogoslof Islands, Aleutian Islands, Alaska: U.S. Geological Survey Bulletio 1028 L, p. 267-369, scale 1:63,360, 1 sheet.

323. Cameron, C.C., Malterer, T.J., Rawlinson, S.E., and Hardy, S. B., 1981a, Surficial geology and peat resources map of the Houston area, Susitna valley, Alaska: U.S. Geological Survey Open-file Report 81-1301, scale 1:15,840, 2 sheets.

324. 1981b, Surficial geology and peat resources map of the Rogers Creek area, Susitna Valley, Alaska: U.S. Geological Survey Open-file Report 81-1302, scale 1:15,840, 3 sheets.

247. Carter, L.D., 1983, Engineering geologic maps of northern Alaska, Teshekpuk Quadrangle: U.S. Geological Survey Open-file Report 83-634, scale 1:250,000, 1 sheet.

229. Carter, L.D., and Galloway, J.P., 1978. Preliminary engineering geologic maps of the proposed natural gas pipeline route in the Tanana River valley, Alaska: U.S. Geological Survey Open-file Repor 78-794, 26 p., scale 1:125,000, 3 sheets. 
254. 1985, Engineering-geologic maps of northern Alaska, Harrison Bay Quadrangle: U.S. Geological Survey Open-file Report 85-256, 49 p., scale 1:250,000, 2 sheets.

260. 1986, Engineering-geologic maps of northem Alaska, Umiat Quadrangle: U.S.

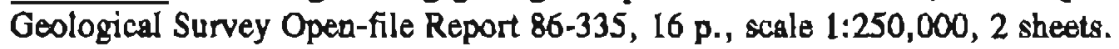

261. 1988, Engineering-geologic maps of northern Alaska, Dkpikpuk River Quadrangle:

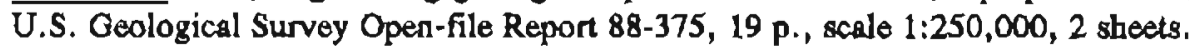

253. Chapman, R.M., Patton, W.W., Jr., and Moll, E.J., 1985, Reconnaissance geologic map of the Ophir Quadrangle, Alaska: U.S. Geological Survey Open-file Report 85-203, 19 p., scale $1: 250,000,1$ sheet.

279. Chapman, R.M., Weber, F.R., and Taber, Bond, 1971, Preliminary geologic map of the Livengood Quadrangle, Alaska: U.S. Geological Survey Open-file Report 71-66 (OF 483), scale 1:250,000, 2 sheats.

154. Chapman, R.M., and Yeend, W.E., 1972, Preliminary geologic map of the northeastern part of the Tanana Quadrangle, Alaska: U.S. Geological Survey Miscellaneous Pield Studies Map MF342 , scale $1: 250,000,1$ sheet.

313. Chapman, R.M., Yeend, W.E., Brosgé, W.P., and Reiser, H.N., 1975, Preliminary geologic map of the Tanana and northeast part of the Kantishna River quadrangles, Alaska: U.S. Geological Survey Open-file Report 75-337, scale 1:250,000, 1 sheet.

239. 1982, Reconnaissance geologic map of the Tanana Quadrangle, Alaska: U.S. Geological Survey Open-file Report 82-734, 20 p., scale 1:250,000, 1 sheet.

312. Chapman, R.M., Yeend. W.E., and Patton, W.W., Jr., 1975, Preliminary reconnaissance geologic map of the western balf of Kantishna River Quadrangle. Alaska: U.S. Geological Survey Open-file Report 75-351, scale 1:250,000,1 sheet.

278. Clark, S.H.B., and Foster, H.L., 1969, Preliminary geologic map of the Eagle D-2 and D-3 quadrangles, Alaska: U.S. Geological Survey Open-file Report 69-43 (OF 349), scale 1:63,360, 1 sheet.

58. Combellick, R.A., 1984a, Surficial geologic map of the Seward D-6 Quadrangle: Alaska Division of Geologic and Geophysical Surveys Report of Investigations 84-15, scale 1:63,360, 1 sheet. $1984 \mathrm{~b}$, Surficial geologic map of the Seward D-7 Quadrangle: Alaska Division of

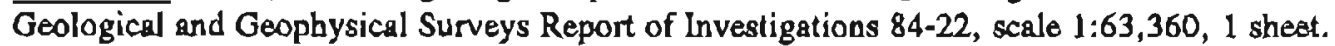

296. 1989, Surficial geology of the U.S. Caast Guard Reservation, Kodiak, Alaska: Alaska Division of Geological and Geophysical Surveys Public-data File 89-8B, 56 p., scale $1: 6,000$ and $1: 12,000,7$ sheets.

68. Combellick, R.A., and Rawlinson, S.E., 1988, Surficial geology of the Mt. Michelson C-1 Quadrangle, northeastern Alaska: Alaska Division of Geological and Genphysical Surveys Report of Investigations 88-16, scale 1:63,360, 1 sheet.

72. Coulter, H.W., and Coulter, E.B., 1961, Valdez (A-5) Quadrangle, Alaska, geology: U.S. Geological Survey Geologic Quadrangle Map GQ-142, scale 1:63,360, 1 sheet. 
109. 1962, Preliminary geologic map of the Valdez-Tiekel Belt, Alaska: U.S. GeologicaY Survey Miscellaneous Investigations Map I-356, scale 1:96,000, 1 sheet.

236. Curtis, S.M., Ellersieck, Inyo, Mayfield, C.F., and Tailleur, I.L., 1982, Reconnaissance geologic map of southwestern Misheguk Mountain Quadrangle, Alaska: U.S. Geological Survey Open-file Report 82-611, 43 p., scale 1:63,360, 2 sheets.

242. 1983, Reconnaissance geologic map of the De Long Mountains AI, B1, and part of C1 quadrangles, Alaska: U.S. Geological Survey Open-file Report 83-185, 54 p., scale $1: 63,360,2$ sheets.

35. Daniels, C.L., 1981a, Geology and geologic-materials maps of Anchorage C-7 SE Quadrangle: Aleska Division of Geological and Geophysical Surveys Geologic Report 67, scale 1:25,000, 2 sheets.

39. 1981b, Geology and geologic-materials maps of Anchorage C-7 SW Quadrangle: Alaska Division of Geological and Geophysical Surveys Geologic Report 71, scale 1:25,000, 2 sheets.

88. Detterman, R.L., 1973, Geologic map of the Iliamna B-2 Quadrangle, Augustine Island, Alaska: U.S. Geological Survey Geologic Quadrangle Map GQ-1068, scale 1:63,360, 1 sheet.

209. Detterman, R.L., and Hartsock, J.K., 1966, Geology of the Iniskin-Tuxedni region, Alaska: U.S. Geological Survey Professional Paper 512, 78 p., scale 1:63,360, 1 sheet.

152. Detterman, R.L., Miller, T.P., Yount, M.E., and Wiłson, F.H., 1981, Quaternary geologic map of the Chignik and Sutwik Island quadrangles, Alaska: U.S. Geological Survey Miscellaneous Investigations Map I-1292, scale I:250,000, 1 sheet.

318. Detterman, R.L., Plafker, George, Hudson, Travis, Tysdal, R.G., and Pavoni, Nazario, 1974, Surface geology and Holocene breaks along the Susitna segment of the Castle Mountain Pault, Alaska: U.S. Geological Survey Miscellanous Field Studies MF-618, scale 1:24,000, 1 sheet.

178. Detterman, R.L., Plafker, George, Tysdal, R.G., and Hudson, Travis, 1976, Geology and surface features along part of the Talkeetna Segment of the Castle Mountain-Caribou fault system, Alaska: U.S. Geological Survey Miscellaneous Field Studies Map MF-738, scale 1:63,360, 1 sheet.

204. Detterman, R.L., and Reed, B.L., 1973, Surficial deposits of the Iliamna Quadrangle, Alaska: U.S. Geological Survey Bulletin 1368 A, p. A1-A64, scale 1:250,000, 1 sheet.

317. Detterman, R.L., Wilson, F.H., Yount, M.E., and Miller, T.P., 1987, Quaternary geologic map of the Ugashik, Bristol Bay, and western part of Karluk quadrangles, Alaska: U.S. Geological Survey Miscellaneous Investigations I-1801, scale 1:250,000, 1 sheet.

54. Dillon, J.T., Adams, D.D., and Adler, Penny, 1983, Geologic map of the Melozitna A-4 Quadrangle: Alaska Division of Geological and Geophysical Surveys Report of Investigations 83-18, scale 1:63,360, 1 sheet.

12. Dillon, J.T., Hamilton, W.B., and Lueck, L.L.. 1981, Geologic map of the Wiseman A-3 Quadrangle: Alaska Division of Geological and Geophysical Surveys Open-file Report 119, scale $1: 63,360$, I sheet. 
43. Dillon, J.T., Pessel, G.H., Lueck, L.L., and Hamilton, W.B., 1987, Geologic map of the Wiseman A-4 Quadrangle, southcentral Brooks Range, Alaska: Alaska Division of Geological and Geophysical Surveys Professional Report 87, scale 1:63,360, 2 sheets.

329. Dillon, J.T., and Reifenstuhl, R.R., 1990, Geologic map of the Wiseman B-1 Quadrangle, southcentral Brooks Range, Alaska: Alaska Division of Geological and Geophysical Surveys Professional Report 101, scale 1:63,360, 1 sheet.

328. Dillon, J.T., Reifenstuhl, R.R., Bakke, A.A., and Adams, D.D., 1990, Geologic map of the Wiseman A-1 Quadrangle, southcentral Brooks Range, Alsska: Alaska Division of Geological and Geophysical Surveys Professional Report 98, scale 1:63,360, 1 sheet.

132. Dobrovolny, Ernest, and Schmoll, H.R., 1974, Slope-stability map of Anchorage and vicinity, Alaska: U.S. Geological Survey Miscellaneous Investigations Map I-787-E, scale 1:24,000, 1 sheet.

237. Ellersiock, Inyo, Curtis, S.M., Mayfield, C.F., and Tailleur, I.L., 1982, Reconnaissance geologic map of south-central Misheguk Mountain Quadrangle, Alaska: U.S. Geological Survey Open-file Report 82-612, 38 p., scale 1:63,360, 2 sheets.

241. 1983, Reconnaissance geologic map of the De Long Mountains A2, B2, and part of C2 quadrangles, Alaska: U.S. Geological Survey Open-file Report 83-184, 54 p., scale I:63,360, 2 sheets.

202. Fernald, A.T., 1964, Surficial geology of the central Kobuk River valley, northwestern Alaska: U.S. Geological Survey Bulletin $1181 \mathrm{~K}$, p. K1-K31, scale 1:250,000, 1 sheet.

284. Ferrians, O.J., 1971a, Preliminary engineering geologic maps of the proposed Trans-Alaska Pipeline route, Beechey Point and Sagavanirktok quadrangles: U.S. Geological Survey Open-file Report 71-101 (OF 491), scale 1:125,000, 2 sheets.

285. 1971b, Preliminary engineering geologic maps of the proposed Trans-Alaska Pipeline route, Philip Smith Mountains Quadrangle: U.S. Geological Survey Open-file Report 71-103 (OF 492), scale $\{: 125,000,2$ sheets.

287. 1971c, Preliminary engineering geologic maps of the proposed Trans-Alaska Pipeline route, Gulkana Quadrangle: U.S. Geological Survey Open-file Report 71-102 (OF 494), scale $1: 125,000,2$ sheets.

288. 1971d, Preliminary engineering geologic maps of the proposed Trans-Alaska Pipeline route, Valdez Quadrangle: U.S. Geological Survey Open-file Report 71-104 (OF 495), scale $1: 125,000,2$ sheets.

120. Foster, H.L., 1970, Reconnaissance geologic map of the Tanacross Quadrangle, Alaska: U.S. Geological Survey Miscellaneous Investigations Map I-593, scale 1:250,000, 1 sheet.

155. 1972, Preliminary geologic map of the Eagle Quadrangle, Alaska: U.S. Geological Survey Miscellaneous Field Studies Map MF-358, scale 1:250,000, I sheet.

144. 1976, Geologic map of the Eagle Quadrangle, Alaska: U.S. Geological Survey Miscollaneous Investigations Map 1-922, scale 1:250,000, 1 sheet. 
223. Poster, H.L., Dusel-Bacon, Cynthia, and Weber, F.R., 1977, Recounaissance geologic map of the Big Delta C-4 Quadrangle, Alaska: U.S. Geological Survey Open-file Report 77-262, scale $1: 63,360,1$ sheet.

133. Freethey, G.W., 1976, Relative permeability of surficial geologic materials, Anchorage and vicinity, Alaska: U.S. Geological Survey Miscellaneous Investigations Map I-787-F, scale $1: 24,000,1$ sheet.

199. Gates, Olcott, Powers, H.A., Wilcox, R.E., and Schafer, J.P., 1971, Geology of the Near Islands, Alaska: U.S. Geological Survey Bulletin 1028 U, p. 709-822, scale 1:63,360, 1 sheet.

3. Gilbert, W.G., 1977, General geology and geochemistry of the Healy D-1 and southern Fairbanks A-1 quadrangles: Alaska Division of Geological and Geophysical Surveys Open-file Report 105, 10 p., scale 1:63,360, 2 sheets.

294. Gilbert, W.G., Bundızen, T.K., Kline, J.T., and Laird, G.M., 1990, Preliminary geology and geochemistry of the southwest part of the Lime Hills D-4 Quadrangle, Alaska: Alaska Division of Geological and Geophysical Surveys Report of Investigations 90-6, scale 1:63,360, 1 sheet.

46. Gilbert, W.G., Solie, D.N., and Kline, J.T., 1988, Geologic map of the McGrath A-3 Quadrangle, Alaska: Alaska Division of Geological and Geophysical Surveys Professional Report 92, scale 1:63,360, 2 sheets.

50. Gilbert, W.G., Solie, D.N., Kline, J.T., and Dickey, D.B., 1990, Geologic map of the McGrath B-3 Quadrangle, Alaska: Alaska Division of Geological and Geophysical Surveys Professional Report 102, scale 1:63,360, 2 sheets.

103. Grantz, Arthur, 1960a, Geologic map of Talkeetna Mountains (A-2) Quadrangle, Alaska, and the contiguous area to the north and northwest: U.S. Geological Survey Miscellaneous Investigations Map I-313, scale $1: 48,000,1$ sheet.

104.

1960b, Geologic map of Talkeetns Mountains (A-1) Quadrangle, and the south third of Talkeetna Mountains (B-1) Quadrangle, Alaska: U.S. Geological Survey Miscellaneous Investigations Map I-314, scale 1:48,000, 1 sheet.

107. 1961a, Geologic map and cross sections of the Anchorage (D-2) Quadrangle and northeastern most part of the Anchorage (D-3) Quadrangle, Alaska: U.S. Geological Survey Miscellaneous Investigations Map I-342, scale 1:48,000, 1 sheet.

108. 1961b, Geologic map of the northern two-thirds of Anchorage (D-1) Quadrangle, Alaska: U.S. Geological Survey Miscellaneous Investigations Map I-343, scale 1:48,000, 1 sheet.

$277 . \quad 1965$, Geologic map and cross-sections of the Nelchina area, southcentral Alaska: U.S. Geological Survey Open-file Report 65-65 (OF 255), scale 1:63,360, 4 sheets.

183. Hamilton, T.D., 1978a, Surficial deposits of the Chandalar Quadrangle, Alaska: U.S. Geological Survey Miscellaneous Field Studies Map MP-878-A, scale 1:250,000, 1 sheet.

184. 1978b, Surficial goologic map of the Philip Smith Mountains Quadrangle, Alaska:

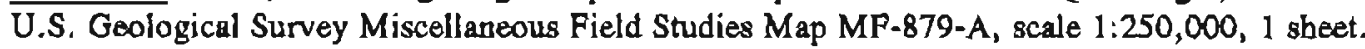

185. 1979a, Surficial geologic map of the Chandler Lake Quadrangle, Alaska: U.S. Geological Survey Miscellaneous Field Studies Map MF-1121, scale 1:250,000, 1 sheet. 
186. 1979b, Surficial geologic map of the Wiseman Quadrangle, Alaska: U.S. Geological Survey Miscellaneous Field Studies Map MF-1122, scale 1:250,000, 1 shoet.

189. 1980, Surficial geologic map of the Killik River Quadrangle, Alaska: U.S. Geological Survey Miscellaneous Field Studies Map MF-1234, scale 1:250,000, 1 sheet.

190. 1981, Surficial geologic map of the Survey Pass Quadrangle, Alaska: U.S. Geological Survey Miscellaneous Field Studies Map MF-1320, scale 1:250,000, 1 sheet.

195. 1984a, Surficial geologic map of the Howard Pass Quadrangle, Alaska: U.S. Geological Survey Miscellaneous Field Studies Map MF-1677, scale 1:250,000, 1 sheet.

196. 1984b, Surficial geologic map of the Amblor River Quadrangle, Alaska: U.S. Geological Survey Miscellaneous Field Studies Map MF-1678, scale 1:250,000, 1 sheet.

250. Hamilton, T.D., and Bauer, D.P., 1984, Engineering-geologic maps of northern Alaska, Howard Pass Quadrangle: U.S. Geological Survey Open-file Report 84-401, scale 1:250,000, 1 sheet.

60. Hickmott, D.R., 1986a, Surficial-geologic map of the Beechey Point A-1 Quadrangle: Alaska Division of Geological and Geophysical Surveys Report of Investigations 86-6, scale 1:63,360, 1 sheet.

61. 1986b, Surficial-geologic map of the Beechey Point A-2 Quadrangle: Alaska Division of Geological and Geophysical Surveys Report of Investigations 86-7, scale 1:63,360, 1 sheet.

114. Hoare, J.M., and Condon, W.H., 1966, Geologic map of the Kwiguk and Black quadrangles, western Alaska: U.S. Geological Survey Miscellanoous Investigations Map I-469, scale $1: 250,000,1$ sheet.

115 , 1968, Geologic map of the Hooper Bay Quadrangle, Alaska: U.S. Geological Survey Miscellaneous Investigations Map I-523, scale 1:250,000, 1 sheet.

124. 1971a, Geologic map of the Marshall Quadrangle, Alaska: U.S. Geological Survey Miscellaneous Investigations Map I-668, scale 1:250,000, 1 sheet.

125. 1971b, Geologic map of the St. Michael Quadrangle, Alaska: U.S. Geological Survey Miscellaneous Investigations Map I-682, scale 1:250,000, 1 sheet.

98. Hoare, J.M., and Coonrad, W.L., 1959a, Geology of the Bethel Quadrangle, Alaska: U.S. Geological Survey Miscellaneous Investigations Map I-285, scale 1:250,000, 1 sheet.

99. 1959b, Geology of the Russian Mission Quadrangle, Alaska: U.S. Geological Survey Miscellaneous Investigations Map I-292, scale 1:250,000, 1 sheet.

105. 1961a, Geologic map of the Hagemeister Island Quadrangle, Alaska: U.S. Geological Survey Miscellaneous Investigations Map 1-321, scale 1:250,000, I sheat.

309. 1961b, Geologic map of the Goodnews Quadrangle, Alaska: U.S. Geological Survey Miscellaneous Investigations I-339, scale $1: 250,000,1$ shoet.

203. Holmes, G.W., and Foster, H.L., 1968, Geology of the Johnson River area, Alaska: U.S. Geological Survey Bulletin 1249, 49 p., scale 1:63,360, 1 sheet. 
73. Holmes, G.W., and Péwe, T.L., 1965, Geologic map of the Mount Hayes D-3 Quadrangle, Alaska: U.S. Geological Survey Geologic Quadrangle Map GQ-366, scale 1:63,360, 1 sheet.

201. Hopkins, D.M., 1963, Geology of the Imuruk Lake area, Seward Peninsula, Alaska: U.S. Geological Survey Bulletin I141 C, p. C1-C101, scale 1:125,000, 1 sheet.

222. 1977, Coastal processes and coastal erosional hazards to the Cape Krusenstern archaeological site: U.S. Geological Survey Open-file Report 77-32, 14 p., scale 1:253,440, 1 sheet.

28. Huck, R.W., and Rawlinson, S.E., 1982, Peat-resource inventory of south-central Alaska, a data report: Alaska Division of Geological and Geophysical Surveys Open-file Report 150, 88 p., scale 1:250,000, 1 sheet.

101. Kachadoorian, Reuben, 1960a, Engineering and surficial geology of the Nenana-Rex area, Alaska: U.S. Geological Survey Miscellaneous Investigations Map I-307, scale 1:63,360, 1 sheet.

102. 1960b, Engineering geology of the Katalla area, Alaska: U.S. Geological Survey Miscellaneous Investigations Map I-308, scale 1:63,360, I sheet.

272. 1960c, Engineering geology bearing on harbor site selection along the Gulf of Alaska from Port Whitshed to Cape Yakataga, Alaska: U.S. Geological Survey Open-file Report 60-85 (OF 188), 32 p., scale 1:40,000, 1 sheet.

281. 1971a, Preliminary engineering geologic maps of the proposed Trans-Alaska Pipeline route, Bettles and Beaver quadrangles: U.S. Geological Survey Open-file Report 71164 (OF 487), scale $1: 125,000,2$ sheets.

283. 1971b, Preliminary engineering geologic maps of the proposed Trans-Alaska Pipelize route, Tanana and Livengood quadrangles: U.S. Geological Survey Open-file Report 71-165 (OF 489), scale 1:125,000, 2 sheets.

280. $1971 \mathrm{c}$, Preliminary engineering geologic maps of the proposed Trans-Alaska Pipeline route, Wiseman and Chandalar quadrangles: U.S. Geological Survey Open-file Report 71-166 (OF 486), scale 1:125,000, 2 sheets.

217. 1974, Geology of the Devil Canyon Dam site, Alaska: U.S. Geological Survey Open-file Report 74-40, 24 p., scale 1:24,000, 1 sheet.

269. Kachadoorian, Reuben, Hopkins, D.M., and Nichols, D.R., 1954, A preliminary report of geologic factors affecting bighway construction in the area between the Susitna-Maclaren Rivers: U.S. Geological Survey Open-file Report 54-137 (OF 92), 73 p., scale 1:40,000, 1 sheet.

270. Kachadoorian, Reuben, and Pewe, T.L., 1955, Engineering geology of the southern half of the Mount Hayes A-5 Quadrangle: U.S. Geological Survey Open-file Report 55-78 (OF 110), 27 p., scale $1: 40,000,1$ sheet.

266. Xachadoorian, Reuben, Sainsbury, C.L., and Hummel, C.L., 1975, Analyses of stream sediment samples from the Teller A-3 Quadrangle, Seward Peninsula, west-central Alaska: U.S. Geological Survey Open-file Report 75-349, 7 p., scale 1:63,360, 1 sheet. 
96. Karlstrom, T.N.V., 1958, Ground conditions and surficial geology of the Kenai-Kasilof area, Kenai Peninsula, south-central Alaska: U.S. Geological Survey Miscellaneous Investigations Map 1-269, scale 1:63,360, 1 sheet.

9. Kline, J.T., 1977, Slope map of the southera Kenai Lowlands: Alaska Division of Geological and Geophysical Surveys Open-file Report 111C, scale 1:63,360, 1 sheet.

6. 1978, Slope map of the Talkeetna-Kashwitns area, Susitna River basin: Alaska Division of Geological and Geophysical Surveys Open-file Report 107C, scale 1:63,360, 1 sheet.

14. 1982, Surficial geology of the lower Pilgrim valley and vicinity, western Seward Peninsula: Alaska Division of Geological and Geophysical Surveys Open-file Report 140, scale $1: 63,360,2$ sheets.

248. Koster, E.A., Galloway, J.P., and Pronk, Toon, 1984, Photo-interpretation map of surficial deposits and landforms of the Nogahabara sand dunes and part of the Koyukuk Lowland, Alaska: U.S. Geological Survey Open-file Report 84-10, scale 1:60,390, 1 sheet.

55. Krause, K.J., 1984, Photointerpretive map of morphological floodplain deposits and material resources, middle Kuskokwim River from Sleetmute to Kalskag: Alaska Division of Geological and Geophysical Surveys Report of Investigations 84-2, 4 p., scale 1:63,360, 5 sheets.

267. Kuhry-Helms, K.P., Koster, E.A., and Galloway, J.P., 1985, Photo-interpretation map of surficial deposits and landforms of the Kobuk Sand Dunes and part of the Kobuk Lowland, Alaska: U.S. Geological Survey Open-file Report 85-242, scale 1:63,360, 1 sheet.

29. Lee, D.E., 1982, Photointerpretive map of the surficial geology of the north Fairbanks D-I and south Livengood A-1 quadrangles: Alaska Division of Geological and Geophysical Surveys Open-file Report 156, scale 1:24,000, 5 sheets.

220. Lemke, R.W., 1975, Reconnaissance engineering geologic map of the Ketchikan area, Alaska, with emphasis on evaluation of earthquake and other geologic hazards: U.S. Geological Survey Open-file Report 75-250, 110 p., scale 1:4,800, 1 sheet.

212. Lemke, R.W., and Yehle, L.A., 1972, Reconnaissance engineering geology of the Haines area, Alaska, with emphasis on evaluation of earthquake and other geologic hazards: U.S. Geological Survay Open-file Report 72-229, 109 p., scale 1:24,000, 2 sheets.

95. Lowe, P.C., Richter, D.H., Smith, R.L., and Schmoll, H.R., 1982, Geologic map of the Nabesna B-5 Quadrangle, Alaska: U.S. Geological Survey Geologic Quadrangle Map GQ-1566, scale $1: 63,360,1$ sheet.

110. MacKevett, E.M., Jr., 1965a, Preliminary geologic map of the McCarthy B-5 Quadrangle, Alaska: U.S. Geological Survey Miscellaneous Investigations Map I-438, scale 1:63,360, 1 sheet.

111. 1965b, Preliminary geologic map of the McCartby C-6 Quadrangle, Alaska: U.S. Geological Survey Miscellaneous Investigations Map I-444, scale 1:63,360, 1 sheet.

82. 1970a, Geologic map of the McCartby C-4 Quadrangle, Alaska: U.S. Geological Survey Geologic Quadrangle Map GQ-844, scale 1:63,360, 1 sheet. 
83. 1970b, Geologic map of the McCarthy C-5 Quadrangle, Alaska: U.S. Geological Survey Geologic Quadrangle Map GQ-899, scale 1:63,360, 1 sheet.

85. 1972, Geologic map of the McCarthy C-6 Quadrangle, Alaska: U.S. Geological Survey Geologic Quadrangle Map GQ-979, scale 1:63,360, 1 sheet.

89. 1974, Geologic map of the McCarthy B-5 Quadrangle, Alaska: U.S. Geological Survey Geologic Quadrangle Map GQ-1146, scale 1:63,360, 1 sheet.

331. MacKevett, E.M., Jr., Berg, H.C., Plafker, George, and Jones, D.L., 1964, Preliminary geologic map of the McCarthy C-4 Quadrangle, Alaska: U.S. Geological Survey Miscellaneous Investigations Map I-423, scale 1:63,360, 1 sheet.

84. MacKevett, E.M., Jr., and Smith, J.G., 1972a, Geologic map of the McCarthy B-4 Quadrangle, Alaska: U.S. Geological Survey Geologic Quadrangle Map GQ-943, scale 1:63,360, 1 sheet.

86. 1972b. Geologic map of the McCartby B-6 Quadrangle, Alaska: U.S. Geological Survey Geologic Quadrangle Map GQ-1035, scale 1:63,360, 1 sheet,

92. MacKevett, E.M., Jr., Smith, J.G., Jones, D.L., and Winkler, G.R., 1978, Geologic map of the McCarthy C-8 Quadrangle, Alaska: U.S. Geological Survey Geologic Quadrangle Map GQ1418 , scale $1: 63,360,1$ sheet.

30. March, G.D., 1982a, Photointerpretive map of the surficial geology of the Skagway B-1 Quadrangle: Alaska Division of Geological and Geophysical Surveys Open-file Report 159, scale $1: 63,360,1$ sheet.

31. 1982b, Photointerpretive map of the surficial geology of the Skagway B-2 Quadrangle: Alaska Division of Geological and Geophysical Surveys Open-file Report 161, scale $1: 63,360,1$ sheet.

53. 1983, Photointerpretive map of the surficial geology of the Skagway A-1 Quadrangle: Alaska Division of Geological and Geophysical Surveys Report of Investigations 83-14, scale $1: 63,360,1$ sheet.

67. 1987, Surficial geology and materials-resources maps of the Skagway A-2 Quadrangle, Alaska: Alaska Division of Geological and Geophysical Surveys Report of Investigations $87-6$, scale $1: 63,360,2$ sheets.

238. Mayfield, C.F., Curtis, S.M., Ellersieck, Inyo, and Tailleur, I.L., 1982, Reconnaissanco geologic map of southeastern Misbeguk Mountain Quadrangle, Alaska: U.S. Geological Survey Open-file Report 82-613, 40 p., scale 1:63,360, 2 sheets.

240. 1983, Reconnaissance geologic map of the De Long Mountains A3, B3, and parts of A4, B4 quadrangles, Alaska: U.S. Geological Survey Open-file Report 83-183, 60 p., scale $1: 63,360,2$ sheets.

249. Mayfield, C.F., Ellersieck, lnyo, and Tailleur, I.L., 1984, Reconnaissance geologic map of the Noatak C5, D5, D6, and D7 quadrangles, Alaska: U.S. Geological Survey Open-file Report 84 396,27 p., scale 1:63,360, 1 sheet.

316. 1987, Reconnaissance geologic map of the Noatak C5, D5, D6, and D7 quadran-

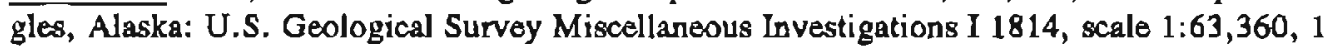
sheet. 
304. McLean, Hugh, Engethardt, C.L., and Howell, D.G., 1978, Reconnaissance geologic map of the Cold Bay and False Pass quadrangles, Alaska: U.S. Geological Survey Open-file Report 78323 , scale $1: 250,000,1$ sheet.

273. Miller, D.J., 1961a, Geology of the Katalla District, Gulf of Alaska Tertiary Province, Alaska: U.S. Geological Survey Open-file Report 61-99 (OF 206), scale 1:96,000, 2 sheets.

274. 1961b, Geology of the Lituye District, Gulf of Alaska Tertiary Province, Alaska: U.S. Geological Survey Open-file Report 61-100 (OF 210), scale 1:96,000, 1 sbeet.

121. 1971, Geology of the Yakataga District, Gulf of Alaska Tertiary Province, Alaska: U.S. Geological Survey Miscellaneous Investigations Map I-610, 6 p., scale 1:125,000, 1 sheet.

321. Miller, R.D., 1972, Surficial geology of the Juneau urban area and vicinity, Alaska, with emphasis on earthquake and other geologic hazards: U.S. Geological Survey Open-file Report $72-255,108$ p., 2 sbeets.

141. 1975, Surficial geologic map of the Juneau urban area and vicinity, Alaska: U.S. Geological Survey Miscellaneous Investigations Map I-885, scale 1:48,000, I sheet.

200. Miller, R.D., and Dobrovolay, Ernest, 1959, Surficial geology of Anchorage and vicinity, Alaska: U.S. Geological Survey Bulletin 1093, 128 p., scale 1:63,360, 6 sheets.

291. Miller, T.P., Grybeck, D.J., Elliott, R.L., and Hudson, Travis, 1972, Preliminary geologic map of the eastern Solomon and southeastern Bendeleben quadrangles, eastern Seward Peninsula, Alaska: U.S. Geological Survey Open-file Report 72-256 (OF 537), 11 p., scale 1:250,000, 1 sheet.

300. Nelson, S.W., and Grybeck, D.J., 1980, Geologic map of the Survey Pass Quadrangle, Brooks Range, Alaska: U.S. Geological Survey Miscellaneous Field Studies MF-1176-A, scale $1: 250,000,2$ sheets.

182. Nelson, S.W., and Reed, B.L., 1978, Surficial deposits of the Talkeetna Quadrangle, Alaska: U.S. Geological Survey Miscellaneous Field Studies Map MF-870-J, scale 1:250,000, 1 sheet.

116. Nichols, D.R., and Yehle, L.A., 1969, Engineering geologic map of the southwestern Copper River basin, Alaska: U.S. Geological Survey Miscellaneous Investigations Map I-524, scale $1: 125,000,1$ sheet.

311. Nokleberg, W.J., Albert, N.R.D., Bond, G.C., Herzon, P.L., Miyaoka, R.T., Nelson, W.H. Richter, D.H., Smith, T.E., Stout, J.H., Yeend, W.E., and Zehner, R.B., 1982, Geologic map of the southern part of the Mount Hayes Quadrangle, Alaska: U.S. Geological Survey Open-file Report 82-52, 26 p., scale 1:250,000, 1 sheet.

57. Nye, C.J., Queen, L.D., and Motyka, R.J., 1984, Geologic map of the Makushin geothermal area, Unalaska Island: Alaska Division of Geological and Geophysical Surveys Report of Investigations 84-3, scale $1: 63,360,2$ sheet.

302. Patton, W.W., Jr., 1966, Regional geology of the Kateel River Quadrangle, Alaska: U.S. Geological Survey Miscellaneous Geologic Investigations I-437, scale 1:250,000, 1 sheet.

113. Patton, W.W., Jr., and Miller, T.P., 1966, Regional geologic map of the Hughes Quadrangle, Alaska: U.S. Geological Survey Miscellaneous Investigations Map I-459, scale 1:250,000, 1 sheet. 
310. 1968, Regional geologic map of the Selawik and southeastera Baird Mourtains quadrangles, Alaska: U.S. Geological Survey Miscellaneous Invastigations I-530, scale 1:250,000, 1 sheet.

325. Patton, W.W., Jr., Miller, T.P., Chapman, R.M., and Yeend, W.E., 1977, Regional geologic map of the Melozitna Quadrangle, Alaska: U.S. Geological Survey Open-file Report 77-147, scale $1: 250,000,1$ sheet.

150. 1978, Geologic map of the Melozitna Quadrangle, Alaska: U.S. Geological Survey Miscellaneous Investigations Map I-1071, scale 1:250,000, 1 sheet.

117. Patton, W.W., Jr., Miller, T.P., and Tailleur, I.L., 1968, Regional geologic map of the Shungnak and southern part of the Ambler River quadrangles, Alaska: U.S. Geological Survey Miscellaneous Investigations Map I-554, scale 1:250,000, I sheet.

301. Patton, W.W., Jr., Moll, E.J., Dutro, J.T., Jr., Silberman, M.L., and Chapman, R.M., 1980, Preliminary geologic map of the Medfra Quadrangle, Alaska: U.S. Geological Survey Open-file Report 80-811 A, scale 1:250,000, 1 sheet.

322. Pavlis, T.L., 1986, Geologic map of the Anchorage C-5 Quadrangle, Alaska: Alagka Division of Geological and Geophysical Surveys Public-data File 86-7, 57 p., scale 1:63,360, 1 sheet.

70. Péwe, T.L., 1958, Fairbanks (D-2), Alaska, geology: U.S. Geological Survey Geologic Quadrangle Map GQ-110, scale 1:63,360, 1 sheet.

137. PEwE, T.L., and Bell, J.W., 1974, Map showing distribution of permafrost in the Fairbanks D2 SW Quadrangle, Alaska: U.S. Geological Survey Miscellaneous Investigations Map I-829-B, scale $1: 24,000,1$ sheet.

160.

1975a, Map showing distribution of permafrost in the Fairbanks D-2 NW Quadrangle, Alaska: U.S. Geological Survey Miscellaneous Field Studies Map MF-668-A, scale $1: 24,000,1$ sheet.

161. 1975b, Map showing ground water conditions in the Fairbanks D-2 NW Quadrangle, Alaska: U.S. Geological Survey Miscellaneous Field Studies Map MF-668-B, scale I:24,000, 1 sheet.

162. 1975c, Map showing construction materials in the Fairbanks D-2 NW Quadrangle, Alaska: U.S. Geological Survey Miscellaneous Field Studies Map MF-668-C, seale 1:24,000, 1 sheet.

163. 1975d, Map showing foundation conditions in the Pairbanks D-2 NW Quadrangle, Alaska: U.S. Geological Survey Miscellaneous Field Studies Map MF-668-D, scale 1:24,000, 2 sheets.

164. 1975e, Map showing distribution of permafrost in the Fairbanks D-2 SE Quadrangle, Alaska: U.S. Geological Survey Miscellaneous Field Studies Map MF-669-A, scale $1: 24,000,1$ sheet.

165. 1975f, Map showing ground water conditions in the Fairbanks D-2 SE Quadrangle, Alaska: U.S. Geological Survey Miscellaneous Field Studies Map MP-669-B, scale 1:24,000, 1 sheet. 
166. 1975g. Map showing construction materials in the Fairbanks D-2 SE Quadrangle, Alaska: U.S. Geological Survey Miscollaneous Field Studies Map MP-669-C, scale 1:24,000, 1 sheet.

167. 1975h, Map showing foundation conditions in the Fairbanks D-2 SE Quadrangle, Alaska: U.S. Geological Survey Miscellaneous Field Studies Map MF-669-D, scale 1:24,000, 2 sheets.

168.

1975i, Map showing distribution of permafrost in the Fairbanks D-2 NE Quadrangle, Alaska: U.S. Geological Survey Miscellaneous Field Studies Map MP-670-A, scale $1: 24,000,1$ sheet.

169. 1975j, Map showing ground water conditions in the Fairbanks D-2 NE Quadrangle, Alaska: U.S. Geological Survey Miscellaneous Field Studies Map MF-670-8, scale 1:24,000, 1 sheet.

170.

1975k, Map showing construction materials in the Fairbanks D-2 NB Quadrangle, Alaska: U.S. Geological Survey Miscellaneous Field Studies Map MF-670-C, scale 1:24,000, 1 sheet.

171. 19751, Map showing foundation conditions in the Fairbanks D-2 NE Quadrangle, Alaska: U.S. Geological Survey Miscellaneous Field Studies Map MF-670-D, scale 1:24,000, 2 sheets.

172. 1975m, Map showing distribution of permafrost in the Pairbanks D-1 SW Quadrangle, Alaska: U.S. Geological Survey Miscellaneous Field Studies Map MF-671-A, scale $1: 24,000,1$ sheet.

173. 1975n, Map showing ground water conditions in the Fairbanks D-1 SW Quadrangle, Alaska: U.S. Geological Survey Miscellaneous Field Studies Map MF-671-B, scale 1:24,000, 1 sheet.

174. 1975o, Map showing construction materials in the Fairbanks D-1 SW Quadrangle, Alaska: U.S. Geological Survey Miscellaneous Field Studies Map MF-671-C, scale 1:24,000, 1 sheet.

175. 1975p, Map showing foundation conditions in the Fairbanks D-1 SW Quadrangle, Alaska: U.S. Geological Survey Miscellaneous Field Studies Map MF-671-D, scale 1:24,000, 2 sheets.

138. 1976a, Map showing groundwater conditions in the Fairbanks D-2 SW Quadrangle, Alaska: U.S. Geological Survey Miscellaneous Investigations Map I-829-C, scale 1:24,000, 1 sheet.

139. 1976b, Map showing construction materials in the Fairbanks D-2 SW Quadrangle, Alaska: U.S. Geological Survey Miscellaneous Investigations Map I-829-D, scale 1:24,000, 1 sheet.

143. Péwé, T.L., Bell, J.W., Forbes, R.B., and Weber, F.R., 1975, Geologic map of the Fairbanks D-2 NW Quadrangle, Alaska: U.S. Geological Survey Miscellaneous Investigations Map I-907, scale $1: 24,000,1$ sheet.

136. 1976a, Geologic map of the Fairbanks D-2 SW Quadrangle, Alaska: U.S. Geological Survey Miscellaneous Investigations Map I-829-A, scale 1:24,000, I sheet. 
146.

1976b, Geologic map of the Fairbanks D-2 SE Qundrangle, Alaska: U.S. Geological Survey Miscellaneous Investigations Map I-942, scale 1:24,000, 1 sheet.

148. 1976c, Geologic map of the Fairbanks D-2 NE Quadrangle, Alaska: U.S. Geological Survey Miscellaneous Investigations Map I-950, scale 1:24,000, 1 sheet.

147. Péwé, T.L., Bell, J.W., Williams, J.R., and Paige, R.A., 1976, Geologic map of the Pairbanks D-1 SW Quadrangle, Alaska: U.S. Geological Survey Miscellaneous Investigations Map I-949, scale $1: 24,000,1$ sheet.

140. 1976c. Map showing foundation conditions in the Fairbanks D-2 SW Quadrangle, Alaska: U.S. Geological Survey Miscellaneous Investigations Map I-829-E, scale 1:24,000, 1 sheet.

330. Péwé, T.L., and Holmes, G.W., 1964, Geology of the Mt. Hayes D-4 Quadrangle, Alaska: U.S. Geological Survey Miscellaneous Investigations Map I-394, scalo 1:63,360, 2 sheets.

271. Péwé, T.L., Hopkins, D.M., and Lachenbruch, A.J., 1959, Engineering geology bearing on harbor site selection along the northwest coast of Alaska from Nome to Point Barrow: U.S. Geological Survey Open-filo Report 59-94 (OF 173), 57 p., scale 1:63,360 and 1:250,000, 5 sheets.

106. Péwe, T.L., and Rivard, N.R., 1961, Geologic map and section of the Pairbanks D-3 Quadrangle, Alaska: U.S. Geological Survey Miscellaneous Investigations Map I-340, scale 1:63,360, 1 sheet.

112. Péwe, T.L., Wahrhaftig, Clyde, and Weber, F.R., 1966, Geologic map of the Fairbanks Quadrangle, Alaska: U.S. Geological Survey Miscellaneous Investigations Map I-455, scale $1: 250,000,1$ sheet.

97. Plafker, George, 1958, Glacial features and surficial deposits of the Malaspina District, Alaska: U.S. Geological Survey Miscellaneous Investigations Map I-271, scale 1:125,000, 1 sheet.

219. 1974, Preliminary geologic map of Kayak and Wingham islands, Alaska: U.S. Geological Survey Open-file Report 74-82, scale 1:31,680, 1 sheet.

257. Plafker, George, Lull, J.S., Nokleberg, W.J., Pessel, G.H., Wallace, W.K., and Winkler, G.R., 1989, Geologic map of the Valdez A-4, B-3, B-4, C-3, C-4 and D-4 quadrangles, northern Chugach Mountains and southern Copper River basin, Alaska: U.S. Geological Survey Open-file Report 89-569, scale 1:63,360, 1 sheet.

207. Post, Austin, 1975, Preliminary hydrography and historic terminal changes of Columbia Glacier, Alaska: U.S. Geological Survey Hydrologic Investigations Atlas HA 559, scale $1: 10,000,3$ sheets.

62. Rawlinson, S.E., 1986a, Surficial-geologic map of the Beechey Point A-3 Quadrangle: Alaska Division of Geological and Geophysical Surveys Report of Investigations 86-8, scale 1:63,360, 1 sheet.

63. 1986b, Surficial-geologic map of the Beechey Point A-4 Quadrangle: Alaska Division of Geological and Geophysical Surveys Report of Investigations 86-9, scale 1:63,360, 1 sheet. 
64. 1986c, Surficial-geologic map of the Beachey Point B-2 Quadrangle: Alaska Division of Geological and Geophysical Surveys Report of Investigations 86-10, scale 1:63,360, 1 sheet.

65. 1986d, Surficial-geologic map of the Beachey Point B-3 Quadrangle: Alaska Division of Geological and Geophysical Surveys Report of Investigations 86-11, scale 1:63,360, 1 sheet.

268. 1986e, Surficial-geologic map of the Beechey Point B-4 Quadrangle, Alaska: Alaska Division of Geological and Geophysical Surveys Report of Investigations 86-12, scale 1:63,360, 1 sheet.

66.

1986f, Peat-resource and surficial-geologic map of the south Kenai Peninsula, Alaska: Alaska Division of Geological and Geophysical Surveys Report of Investigations 86-15, scale 1:31,680, 1 sheet.

297. 1990, Surficial geology and morphology of the Alaskan central Arctic Caastal Plain: Alaska Division of Geological and Geophysical Surveys Public-data File 90-27, 311 p. , scale $1: 63,360,6$ sheets.

15. Rawlinson, S.E., Huck, R.W., and Hardy, S.B., 1982a, Peat-resource map, south-central Talkeetna B-1 Quadrangle: Alaska Division of Geological and Geophysical Surveys Open-file Report 150A, scale 1:15,840, 1 sheet.

16. 1982b, Peat-resource map, southwestern Talkeetra B-1 Quadrangle: Alaska Division of Geological and Geophysical Surveys Open-file Report 150B, scale 1:15,840, 1 sheet.

20.

1982c, Peat-resource map, north-central Talkeetna A-1 Quadrangle: Alaska Division of Geological and Geophysical Surveys Open-file Report 150C, scale 1:15,840, 1 sheet.

1982d, Peat-resource map, nortbwestern Talkeetra A 1 Quadrangle: Alaska Division of Geological and Geophysical Surveys Open-file Report 150D, scale 1:15,840, 1 sheet.

1982e, Peat-resource map, southeastern Talkeema A-1 and southwestem Talkeetna Mountains A-6 quadrangles: Alaska Division of Geological and Geophysical Surveys Open-file Report 150E, scale 1:15,840, 1 sheet.

1982f, Peat-resource map, south-central Talkeetna A-1 Quadrangle: Alaska Division of Geological and Geophysical Surveys Open-file Report 150F, scale 1:15,840, 1 sheot.

21. 1982g, Peat-resource map, southwestern Talkeetna A-1 Quadrangle: Alaska Division of Geological and Geophysical Surveys Open-file Report 150G, scale 1:31,680, 1 sheet.

22. 1982h, Peat-resource map, western Anchorage D-8 Quadrangle: Alaska Division of Geological and Geophysical Surveys Open-file Report 150H, scale 1:31,680, 1 sheet.

23. 1982i, Peat-resource map, Tyonek D-1 Quadrangle: Alaska Division of Geological and Geophysical Surveys Open-file Report 150I, scale 1:31,680, 1 sheet.

24. 1982j, Peat-resource map, Anchorage C-8 Quadrangle: Alaska Division of Geological and Geophysical Surveys Open-file Report 150J, scale 1:31,680, 1 sheet.

25. 1982k, Peat-resource map, Tyonek C-1 Quadrangle: Alaska Division of Geological and Geophysical Surveys Open-file Report 150K, scale 1:31,680, 1 sheet. 
26. 19821, Peat-resource map, Anchorage B-8 Quadrangle: Alaska Division of Geological and Geophysical Surveys Open-file Report 150L, scale 1:31,680, 1 sheet.

27. 1982m, Peat-resource map, Tyonek B-1 Quadrangle: Alaska Division of Geological and Geophysical Surveys Open-file Report 150M, scale 1:31,680, 1 sheet.

181. Reed, B.L., and Nelson, S.W., 1977, Geologic map of the Talkeetna Quadrangle, Alaska: U.S. Geological Survey Miscellaneous Field Studies Map MF-870-A, scale 1:250,000, 1 sheet.

151. 1980, Geologic map of the Talkeetna Quadrangle, Alaska: U.S. Geological Survey Miscellanoous Investigations Map 1-1174, scale 1:250,000, 1 sheet.

265. Reed, J.C., Jr., 1961, Geology of the Mount McKinley Quadrangle, Alaska: U.S. Geological Survey Bulletin 1108 A, p. A1-A36, scale 1:250,000, 1 sheet.

7. Reger, R.D., 1977. Photointerpretive map of the surficial geology of the southern Kenai Lowlands: Alaska Division of Geological and Geophysical Surveys Open-file Report 111A, scale $1: 63,360,1$ sheet.

4. 1978, Reconnaissance geology of the Talkeetna-Kashwitna area, Susitas River basin: Alaska Division of Geological and Geophysical Surveys Open-file Report 107A, scale 1:63,360, 1 sheet.

34.

1981a, Geology and geologic-materials maps of Anchorage C-8 SE Quadrangle: Alaska Division of Geological and Geophysical Surveys Geologic Report 65, scale 1:25,000, 2 sheets.

36. $1981 \mathrm{~b}$, Geology and geologic-materials maps of Anchorage C-8 SW Quadrangle: Alaska Division of Geological and Geophysical Surveys Geologic Report 68, scale 1:25,000, 2 sheets.

37. 1981c, Geology and geologic-materials maps of Anchorage B-8 NE Quadrangle: Alaska Division of Geological and Geophysical Surveys Geologic Report 69, scale 1:25,000, 2 sheets.

38. 1981d, Geology and geologic-materials maps of Anchorage B-8 NW Quadrangle: Alaska Division of Geological and Geophysical Surveys Geologic Report 70, scale 1:25,000, 2 sheets.

8. Reger, R.D., and Carver, C.L., 1977, Photointerpretive map of the geologic materials of the southem Kenai Lowlands: Alaska Division of Geological and Geophysical Surveys Open-file Report 111B, scale 1:63,360, 1 sheet.

5. 1978a, Reconnaissance map of geologic materials, Talkeetna-Kashwitna area, Susitna River basin: Alaska Division of Geological and Geophysical Surveys Open-file Report 107B, scale 1:63,360, 1 sheet.

10.

1978b, Reconnaissance geology of the new capital site and vicinity, Anchorage Quadrangle: Alaska Division of Geological and Geophysical Surveys Open-file Report 113A, scale $1: 63,360,1$ sheet.

11.

1978c, Reconnaissance geologic materials map of the new capital site and vicinity. Anchorage Quadrangle: Alaska Division of Geological and Geophysical Surveys Open-file Report 113B, scale 1:63,360, 1 sheet. 
262, Reihle, J.R., Detterman, R.L., Yount, M.E., and Miller, J.W., 1987, Preliminary geologic map of the Mt Katmai Quadrangle and portions of the Afognak and Naknek quadrangles, Alaska: U.S. Geological Survey Open-file Report 87-593, scale 1:250,000, 1 sheet.

226. Reiser, H.N., Brosge, W.P., Detterman, R.L., and Dutro, J.T., Jr., 1978, Geologic map of the Demarcation Point Quadrangle, Alaska: U.S. Geological Survey Open-file Report 78-526, scale 1:200,000, 1 sheet.

299. Reiser, H.N., Brosge, W.P., Dutro, J.T., Jr., and Detterman, R.L., 1971, Preliminary geologic map, Mt. Michelson Quadrangle, Alaska: U.S. Geological Survey Open-file Report $71-$ 237 (OF 490), scale 1:200,000, 2 sheets.

308. 1980, Geologic map of the Demarcation Point Quadrangle, Alaska: U.S. Geological Survey Miscellaneous Investigations I-1133, scale 1:250,000, I sheet.

122. Richter, D.H., 1971a, Reconnaissance geologic map and sections of the Nabesna A-3 Quadrangle, Alaska: U.S. Geologica! Survey Miscellaneous Investigations Map I-655, scale 1:63,360, 1 sheet.

123. 1971b, Reconnaissance geologic map of the Nabesna B-4 Quadrangle, Alaska: U.S. Geological Survey Miscellaneous Investigations Map 1-656, scale 1:63,360, 1 sheet.

134. 1973, Reconnaissance geologic map of the Nabesna A-4 Quadrangle, Alaska: U.S.

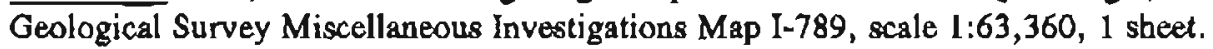
1975, Reconnaissance geologic map of the Nabesna B-3 Quadrangle, Alaska: U.S. Geological Survey Miscellaneous Investigations Map I-904, scale 1:63,360, 1 sheet.

145. 1976, Geologic map of the Nabesna Quadrangle, Alaska: U.S. Geological Survey Miscellaneous Investigations Map [-932, scale 1:250,000, 1 sheet.

127. Richter, D.H., and Jones, D.L., 1973, Reconnaissance geologic map of the Nabesna A-2 Quadrangle, Alaska: U.S. Geological Survey Miscellaneous Investigations Map I-749, scale $1: 63,360,1$ sheet.

135. Richter, D.H., Matson, N.A., Jr., and Schmoll, H.R., 1973, Reconnaissance geologic map of the Nabesna A-1 Quadrangle, Alaska: U.S. Geological Survey Miscellaneous Investigations Map I-807, scale 1:63,360, I sheet.

91. 1976, Geologic map of the Nabesna C-4 Quadrangle, Alaska: U.S. Geological Survey Geologic Quadrangle Map GQ-1303, scale 1:63,360, 1 sheet.

256. Richter, D.H., Ratte, J.C., Schmoll, H.R., Leeman, W.P., Smith, J.G., and Yehle, L.A., 1989, Geologic map of the Gulkana B-1 Quadrangle, south-central Alaska: U.S. Geological Survey Geologic Quadrangle Map GQ 1655, scale 1:63,360, 1 sheet.

87. Richter, D.H., and Schmoll, H.R., 1973, Geologic map of the Nabesna C-5 Quadrangle, Alaska: U.S. Geological Survey Geologic Quadrangle Map GQ-1062, scale 1:63,360, 1 sheet.

149. Richter, D.H., Sharp. W.N., Dutro, J.T., Jr., and Hamilton, W.B., 1977, Geologic map of parts of the Mount Hayes A-1 and A-2 quadrangles, Alaska: U.S. Geological Survey Miscellaneous Investigations Map I-1031, scale 1:63,360, 1 sheet. 
90. Richter, D.H., and Smith, R.L., 1976, Geologic map of the Nabesas A-5 Quadrangle, Alaska: U.S. Geological Survey Geologic Quadrangle Map GQ-1292, scale 1:63,360, 1 sheet.

93. Richter, D.H., Smith, R.L., Yehle, L.A., and Miller, T.P., 1979, Geologic map of the Gulkana A-2 Quadrangle, Alaska: U.S. Geological Survey Geologic Quadrangle Map GQ-1520, scale $1: 63,360,1$ sheet.

33. RiehJe, J.R., and Emmel, K.S., 1980, Photointerpretation map of the surficial geology, Polly Creek to McArthur River, Cook Inlet: Alaska Division of Geological and Geophysical Surveys Geologic Report 64, scale 1:63,360, 2 sheets.

49. Robinson, M.S., Decker, John, Clough, J.G., Reifenstuhl, R.R., Bakke, A.A., Dillon, J.T., Combellick, R.A., and Rawlirson, S.E., 1989, Geology of the Sadlerochit and Shublik Mountains, Arctic National Wildlife Rofuge, northeastem Alaska: Alaska Division of Geological and Geophysical Surveys Professional Report 100, scale 1:63,360, 1 sheet.

210. Sable, E.G., 1977, Geology of the western Romanzof Mountains, Brooks Range, northeastern Alaska: U.S. Geological Survey Professional Paper 897, 84 p., scale 1:63,360, 1 sheet.

118. Sainsbury, C.L., 1969, Geologic map of the Teller B-4 and southern part of the Teller C-4 quadrangles, western Seward Peninsula, Alaska: U.S. Geological Survey Miscellaneous Investigations Map I-572, scale 1:63,360, 1 sheet.

126. 1972, Geologic map of the Teller Quadrangle, westem Seward Peninsula, Alaska: U.S. Geological Survey Miscellaneous Investigations Map I-685, scale 1:250,000, 1 sheot.

213. Sainsbury, C.L., Hudson, Travis, Ewing, Rodney, and Marsh, W.R., 1972a, Reconnaissance geologic map of the Nome C-2 Quadrangle, Seward Peninsula, Alaska: U.S. Geological Survey Open-file Report 72-321 (OF 506), 13 p., scale 1:63,360, 1 sheet.

214. 1972b, Reconnaissance geologic map of the Nome C-3 Quadrangle, Seward Peninsula, Alaska: U.S. Geological Survey Open-file Report 72-322 (OF 510), 9 p., scale 1:63,360, 1 sheet.

290.

1972c, Reconnaissance geologic maps of the Solomon D-5 and C-5 quadrangles, Seward Peninsula, Alaska: U.S. Geological Survey Open-file Report 72-323 (OF 511), 12 p., scale $1: 63,360,1$ sheet.

293.

1972d, Reconnaissance geologic map of the west balf of the Solomon Quadrangle, Alaska: U.S. Geological Survey Open-file Report 72-324 (OF 544), 10 p., scale 1:250,000, 1 sheet.

292. Sainsbury, C.L., Hummel, C.L., and Hudson, Travis, 1972, Reconnaissance geologic map of the Nome Quadrangle, Seward Peninsula, Alaska: U.S. Geological Survey Open-file Report $72-$ 326 (OF 543), 28 p., scale 1:250,000, 1 sheet.

327. Sainsbury, C.L., Kachadoorian, Reuben, Hudson, Travis, Smith, T.E., Richards, T.R., and Todd, W.E., 1969, Reconnaissance geologic maps and sample data, Teller A-1, A-2, A-3, B-1, B-2, B-3, C-1 and Bendeleben A-6, B-6, C-6, D-5, and D-6 Quadrangles, Seward Peninsula, Alaska: U.S. Geological Survey Open-file Report 69-236 (OF 377)، 60 p., scale 1:63,360, 13 sheets. 
215. Sainsbury, C.L., Smith, T.B., and Kachadoorian, Reuben, 1972, Roconnaissance geologic map of the Nome D-3 Quadrangle, Seward Peninsula, Alaska: U.S. Geological Survey Open-file Report 72-327 (OF 514), 10 p., scale 1:63,360, 1 sheet.

289. Schmoll, H.R., and Dobrovolny, Emest, 1971, Generalized geologic map of the Eagle RiverBirchwood area, greater Anchorage Borough area, Alaska: U.S. Geological Survey Open-file Report 71-248 (OF 503), scale 1:63,360, 1 sheet.

128. 1972a, Generalized geologic map of Anchorage and vicinity, Alaska: U.S. Geological Survey Miscellaneous Investigations Map I-787-A, scale 1:24,000, 1 sheet.

129. 1972b, Slope map of Anchorage and vicinity, Alaska: U.S. Geological Survey Miscellaneous Investigations Map I-787-B, scale 1:24,000, 1 sheet.

130. 1973, Construction materials map of Anchorage and vicinity, Alaska: U.S. Geological Survey Miscellaneous Investigations Map I-787-C, scale 1:24,000, 1 sheet.

131. 1974, Foundation and excavation conditions map of Anchorage and vicinity, Alaska: U.S. Geological Survey Miscellaneous Investigations Map I-787-D, scale 1:24,000, 1 sheet.

230. Schmoll, H.R., Dobrovolny, Ernest, and Gardaer, C.A., 1980, Preliminary geologic map of the middle part of the Eagle River valley, Municipality of Anchorage, Alaska: U.S. Geological Survey Open-file Report 80-890, 12 p., scale 1:25,000, 1 sheet.

233. 1981, Preliminary geologic map of Fire Island, Municipality of Anchorage, Alaska: U.S. Geological Survey Open-file Report 81-552, 5 p., scale 1:25,000, 1 sheet.

235. Schmoll, H.R., and Emanuel, R.P., 1981, Generalized geologic map and hydrologic properties of the Potter Creek area, Municipality of Anchorage, Alaska: U.S. Geological Survey Open-file Report 81-1168, scale 1:25,000, 1 sheet.

246. 1983, Geologic materials and hydrogeologic characteristics in the Fire LakesEklutna area, Anchorage, Alaska: U.S. Geological Survey Open-file Report 83-479, scale $1: 25,000,1$ sheet.

319. Schmoll, H.R., and Yehle, L.A., 1987, Surficial geologic map of the northwestern quarter of the Tyonek A-4 Quadrangle, south-central Alaska: U.S. Geological Survey Miscellaneous Field Studies MF-1934, scale 1:31,680, 1 sheet.

232. Schmoll, H.R., Yehle, L. A., and Gardner, C.A., 1981, Preliminary geologic map of the Congahbuna area, Cook Inlet region, Alaska: U.S. Geological Survey Open-file Report 81 429, 9 p., scale 1:63,360, 1 sheet.

205. Smith, J.G., 1977, Geology of the Ketchikan D-1 and Bradfield Canal A-1 quadrangles, southestera Alaska: U.S. Geological Survey Bulletin 1425, 49 p., scale 1:63,360, 1 sheet.

32. Smith, T.E., 1981, Geology of the Clearwater Mountains, south-central Alaska: Alaska Division of Geological and Geophysical Surveys Geologic Report 60, 72 p., scale 1:63,360, 3 sheets.

47. Smith, T.E., Albanese, M.D., and Kline, G.L., 1988, Geologic map of the Healy A-2 Quadrangle, Alaska: Alaska Division of Geological and Geophysical Surveys Professional Report 95 , scale $1: 63,360,1$ sheet, 
197. Snyder, G.L., 1959, Geology of Little Sitkin Island, Alaska: U.S. Geological Survey Bulletin $1028 \mathrm{H}$, p. 169-210, scale 1:20,000, 1 sheet.

295. Solie, D.N., Gilbert, W.G., Harris, E.E., Kline, J.T., Liss, S.A., and Robinson, M.S., 1991, Proliminary geologic map of the Tyonek D-6 and eastern Tyonok D-7 quadrangles, Alaska: Alaska Division of Geological and Geophysical Surveys Public-data File 91-10, 16 p., scale $1: 40,000,1$ sheet.

255. Till, A.B., Dumoulin, J.A. , Gamble, B.M., Kaufman, D.S., and Carrol, P.I., 1986, Preliminary geologic map and fossil data, Solomon, Bendeleben, and southern Kotzobue quadrangles, Seward Peninsula, Alaska: U.S. Geological Survey Open-file Report 86-276, 60 p., scale $1: 250,000,3$ sheats.

179. Tysdal, R.G., Hudson, Travis, and Plafker, George, 1976, Geologic map of the Cordova B-2 Quadrangle and northem part of the Cordova A-2 Quadrangle, south-central Alaska: U.S. Geological Survey Miscellaneous Field Studies Map MF-783, scale 1:63,360, 1 sheet.

153. Updike, R.G., 1986, Engineering geologic maps of the Govemment Hill area, Anchorage. Alaska: U.S. Geological Survey Miscellaneous Investigations Map I-1610, scale 1:4,800, 1 sheet.

69. Updike, R.G., and Howland, M.D., 1979, Surficial geology and processes, Prudhoe Bay Oil Field, with hydrologic implications: Alaska Division of Geological and Geophysical Surveys Special Report 16, 6 p., scale 1:12,000, 17 sheets.

51. Updike, R.G., and Ulery, C.A., 1983, Preliminary geologic map of the Anchorage B-6 NW (EkJutna Lake) Quadrangle: Alaska Division of Geological and Geophysical Surveys Report of Investigations 83-8, scale 1:10,000, 2 sheets.

44. 1984, Engineering-geology map of southwest Anchorage: Alaska Division of Geological and Geophysical Surveys Professional Report 89, scale 1:15,840, 1 sheet.

1. Wahrhaftig, Clyde, 1958, Quatemary geology of the Nenana River valley and adjacent parts of the Alaska Range: U.S. Geological Survey Professional Paper 293 A, p. 1-78, scale 1:63,360, 8 sheets.

74. 1970a, Geologic map of the Healy D-2 Quadrangle, Alaska: U.S. Geological Survey Geologic Quadrangle Map GQ-804, scale 1:63,360, 1 sheet.

75. 1970b, Geologic map of the Healy D-3 Quadrangle, Alaska: U.S. Geological Survey Geologic Quadrangle Map GQ-805, scale 1:63,360, 1 sheel.

76. 1970c, Geologic map of the Healy D-4 Quadrangle, Alaska: U.S. Geological Survey Geologic Quadrangle Map GQ-806, scale 1:63,360, 1 sheet.

77. - 1970d, Geologic map of the Healy D-5 Quadrangle, Alaska: U.S. Geological Survey Geologic Quadrangle Map GQ-807, scale 1:63,360, 1 sheet.

78. 1970e, Geologic map of the Fairbanks A-2 Quadrangle, Alaska: U.S. Geological Survey Geologic Quadrangle Map GQ-808, scale 1:63,360, 1 sheet.

79. 1970f, Geologic map of the Fairbanks A-3 Quadrangle, Aleska: U.S. Geological Survey Geologic Quadrangle Map GQ-809، scale 1:63,360, 1 sheet. 
80. 1970g, Geologic map of the Fairbanks A-4 Quadrangle, Alaska: U.S. Geological Survey Geologic Quadrangle Map GQ-810, scale 1:63,360, 1 sheet.

81. 1970h, Geologic map of the Fairbanks A-5 Quadrangle, Alaska: U.S. Geological Survey Geologic Quadrangle Map GQ-811, scale 1:69,360, 1 sheet.

208. Wahrhaftig, Clyde, and Black, R.F., 1958, Engineering geology along part of the Alaska Railroad: U.S. Geological Survey Professional Paper 293 B, p. 79-118, scale 1:63,360, 6 sheets.

206. Waller, R.M., Feulner, A.J., and Morris, D.A., 1968, Water resources and surficial geology of the Homer area, south-central Alaska: U.S. Geological Survey Hydrologic Investigations Atlas HA 187, scale 1:63,360, 1 sheet.

298. Waythomas, C.F., 1991, Surficial geologic maps of the Sagavanirktok A-1, A-2, and B-2 quadrangles, northeastern Brooks Range, Alaskn: Alaska Division of Geological and Geophysical Surveys Public-data File 91-21A, scale 1:63,360, 3 sheets.

56. Waytbomas, C.F., TenBrink, N.W., and Ritter, D.F., 1984, Surficial geology of the Livengood B-3, B-4, C-3, and C-4 quadrangles: Alaska Division of Geological and Geophysical Surveys Report of Investigations 84-6, scale 1:63,360, 1 sheet.

275. Weber, F.R., 1961, Reconnaissance engineering geology for selection of a bighway route from Talkeetna to McGrath, Alaska: U.S. Geological Survey Open-file Report 61-169 (OF 224), scale $1: 250,000,2$ sheets. 71-317 (OF 488), scale 1:125,000, 2 sheets. Pipeline route, Mt. Hayes Quadrangle: U.S. Geological Survey Open-file Report 71-318 (OF 493), scale 1:125,000, 2 sheets.

180. Weber, F.R., Foster, H.L., and Keith, T.E.C., 1977, Reconnaissance geologic map of the Big Delta A-2 and A-3 quadrangles, Alaska: U.S. Geological Survey Miscellaneous Field Studies Map MP-869, scale 1:63,360, 1 sheet.

177. Weber, F.R., Foster, H.L., Keith, T.E.C., and Cantelow, A.L., 1975, Reconnaissance geologic map of the Big Delta A-1 and B-1 quadrangles, Alaska: U.S. Geological Survey Miscellaneous Field Studies Map MF-676, scale 1:63,360, 1 sheet.

227. Weber, F.R., Foster, H.L., Keith, T.E.C., and Dusel-Bacon, Cynthia, 1978, Preliminary geologic map of the Big Delta Quadrangle, Alaska: U.S. Geological Survey Open-file Report 78529 A, scale $1: 250,000,1$ sheet.

119. Weber, F.R., and Péwe, T.L., 1970, Surficial and engineering geology of the central part of the Yukon-Koyukuk Lowland, Alaska: U.S. Geological Survey Miscellaneous Investigations Map I590 , scale $1: 125,000,2$ sheets.

100. Williams, J,R., 1957, Geology of the wastern part of the Big Delta (D-6) Quadrangle, Alaska: U.S. Oeological Survey Miscellaneous Investigations Map I-297, scale 1:63,360, 1 sheet.

71. 1959, Fairbanks (D-1), Alaska, geology: U.S. Geological Survey Geologic Quadrangle Map GQ-124, scale 1:63,360, 1 sheet. 
244. 1983a, Engineering-geologic maps of northem Alaska, Meade River Quadrangle: U.S. Geological Survey Open-file Report 83-294, 32 p., scale 1:250,000, 1 sheet.

245. 1983b, Engineering-geologic maps of northern Alaska, Wainwright Quadrangle: U.S. Geological Survey Open-file Report 83-457, 30 p., scale 1:250,000, 1 sheet.

252. 1985, Engineering-geologic map of southwestern Copper River basin and upper Matanuska River valley, Alaska: U.S. Geological Survey Open-file Report 85-143, scale 1:125,000, 2 sheets.

326. Williams, J.R., and Carter, L.D., 1984, Engineering-geologic maps of northern Alaska, Barrow Quadrangle: U.S. Geological Survey Open-file Report 84-124, 39 p., scale 1:250,000, 2 sheets.

231. Williams, J.R., and Johnson, K.M., 1980, Map and description of late Tertiary and Quatemary deposits, Valdez Quadrangle, Alaska: U.S. Geological Survey Open-file Report 80-892 C, scale 1:250,000, 2 sheets.

225. Williams, J.R., Yeend, W.E., Carter, L.D., and Hamilton, T.D., 1977, Preliminary surficial deposits map, National Petroleum Reserve, Alaska: U.S. Geological Survey Open-file Report 77-868, scale $1: 500,000,2$ sheets.

305. Winkler, G.R., 1973, Geologic map of the Cordova A-7 and A-8, B-6, B-7, and B-8 quadrangles, Hinchinbrook Island, Alaska: U.S. Geological Survey Miscellaneous Field Studies MP531, scale 1:63,360, 1 sheot.

94. Winkler, G.R., and MacKevett, E.M., Jr., 1981, Geologic map of the McCarthy C-7 Quadrangle, Alaska: U.S. Geological Survey Geologic Quadrangle Map GQ-1533, scale 1:63,360, 1 sheet.

234. Winkler, G.R., and Plafker, George, 1981, Geologic map and cross sections of the Cordova and Middleton Island Quadrangles, southern Alaska: U.S. Geological Survey Open-file Report 81 1164,26 p., scale 1:250,000, 1 sheet.

156. Yeend, W.E., 1973a, Preliminary geologic map of a prospective transportation route from Prudhoe Bay, Alaska, to Canadian border, Part 1, Beechey Point and Sagavanirktok quadrangles: U.S. Geological Survey Miscellaneous Field Studies Map MF-489, scale 1:125,000, 2 sheets,

157. 1973b, Preliminary geologic map of a prospective transportation route from Prudhoe Bay, Alaska, to Canadian border; Part II, Mt. Michelson Quadrangle, Alaska: U.S. Geological Survey Miscellaneous Field Studies Map MF-494, scale 1:125,000, 2 sheets.

158. 1973c, Preliminary geologic map of a prospective transportation route from Prudhoe Bay, Alaska, to Canadian border; Part V, Coleen Quadrangle (north half), Alaska: U.S. Geological Survey Miscellaneous Field Studies Map MF-502, scale 1:125,000, 2 sheets.

243. 1983, Engineering-geologic maps of northern Alaska, Loakout Ridge Quadrangle: U.S. Geological Survey Open-file Report 83-279, scale 1:250,000, 2 sheets.

251. 1984, Engineering-geologic maps of northern Alaska, Utukok River Quadragle:

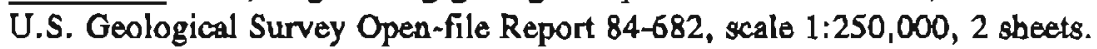


315. Yeend, W.E., and Brosge, W.P., 1973a, Preliminary geologic map of a prospective transportation route from Prudhoe Bay, Alaska, to Canadian border; Part III, Arctic Quadrangle (north half), Alaska: U.S. Geological Survey Miscollaneous Field Studies MF-501, scale 1:125,000, 2 sheets. Bay, Alaska, to Canadian border; Part IV, Arctic and Table Mta. quadrangles: U.S. Geological Survey Miscellaneous Field Studies MF-522, scale 1:125,000, 2 sheets.

218. Yehle, L.A., 1974, Reconnaissance engineering geology of Sitka and vicinity, Alaska, with emphasis on evaluation of earthquake and other geologic hazards: U.S. Geological Survey Openfile Report 74-53, 104 p., scale 1:9,600, 3 sheets.

221.

1975, Preliminary report on the reconnaissance engineering geology of the Yakutat area, Alaska, with emphasis on evaluation of earthquake and other geologic hazards: U.S. Geological Survey Open-file Report 75-529, 136 p., scale 1:63,360, 2 sheets.

224.

1977, Reconnaissance engineering geology of the Metlakatla area, Annette Island, Alaska, with emphasis on evaluation of earthquake and other geologic hazards: U.S. Geological Survey Open-file Report 77-272, 93 p., scale 1:9,600 and 1:250,000, 4 sheets.

228. 1978, Reconnajssance engineering geology of the Petersburg area, southeastern Alaska, with emphasis on geologic hazards: U.S. Geological Survey Open-file Report 78-675, 92 p., scale $1: 9,600$ and $1: 250,000,2$ sheets.

211. 1979, Reconnaissance engineering geology of the Yakutat area, Alasks, with emphasis on evaluation of earthquake and other geologic hazards: U.S. Geological Survey Professional Paper 1074, 44 p., scale 1:63,360, 1 sheet.

187. 1980, Preliminary surficial geologic map of the Valdez C-1 Quadrangle, Alaska: U.S. Geological Survey Miscellaneous Field Studies Map MF-1132, scale 1:63,360, 1 sheet.

191. 1981, Preliminary surficial geologic map of the Valdez B-1 Quadrangle, Alaska:

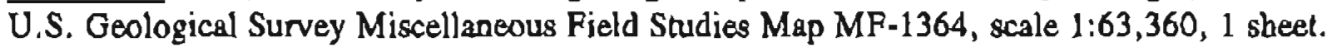

216. Yehle, L.A., and Lemke, R.W., 1972, Reconnaissance engineering geology of the Skagway area, Alaska, with emphasis on evaluation of earthquake and other geologic hazards: U.S. Geological Survey Open-file Report 72-454, 108 p., scale 1:9,600, 2 sheets.

188. Yehle, L.A., and Nichols, D.R., 1980, Reconnaissance map and description of the Chetaslina volcanic debris flow (new name), southeastern Copper River basin and adjacent areas, southcentral Alaska: U.S. Geological Survey Miscellaneous Field Studies Map MF-1209, scale $1: 250,000,1$ sheet.

264. Yehle, L.A., and Schmoll, H.R., 1987a, Surficial geologic map of the Anchorage B-7 NW Quadrangle, Alaska: U.S. Geological Survey Open-file Report 87-168, 12 p., scale 1:25,000, 2 sheets.

263. 1987b, Surficial geologic map of the Anchorage B-7 NE Quadrangle, Alaska: U.S.

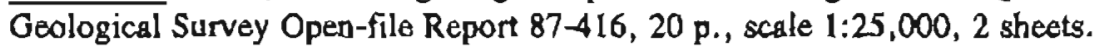


258. 1989, Surficial geologic map of the Anchorage B-7 SW Quadrangle, Alaska: U.S. Geological Survey Open-file Report 89-318, 34 p., scale 1:25,000, 2 sheets.

193. Yehle, L.A., Schmoll, H.R., and Chleborad, A.F., 1983a, Preliminary surficial geologic map of the southwestern part of the Tyonek B-5 Quadrangle, Alaska: U.S. Geological Survey Miscellaneous Field Studies Map MF-1661-B, scale 1:31,680, 1 sheet.

194. 1983b, Preliminary surficial geologic map of the southeastern part of the Tyonek B5 Quadrangle, Alaska: U.S. Geological Survey Miscellaneous Field Studies Map MP-1661-C, scale $1: 31,680,1$ sheet.

192. Yehle, L.A., Schmoll, H.R., and Gardner, C.A., 1983, Preliminary surficial geologic map of the northern part of the Tyonek B-5 Quadrangle, Alaska: U.S. Geological Survey Miscellaneous Field Studies Map MP-1661-A, scale 1:31,680, 1 sheet. 